Florida International University FIU Digital Commons

FIU Electronic Theses and Dissertations

University Graduate School

9-10-2012

\title{
Essays in Economic Growth, Political Economy and Institutions
}

Ece Handan Guleryuz

Florida International University, egule001@fiu.edu

DOI: $10.25148 /$ etd.FI12110705

Follow this and additional works at: https://digitalcommons.fiu.edu/etd

\section{Recommended Citation}

Guleryuz, Ece Handan, "Essays in Economic Growth, Political Economy and Institutions" (2012). FIU Electronic Theses and Dissertations. 720.

https://digitalcommons.fiu.edu/etd/720

This work is brought to you for free and open access by the University Graduate School at FIU Digital Commons. It has been accepted for inclusion in FIU Electronic Theses and Dissertations by an authorized administrator of FIU Digital Commons. For more information, please contact dcc@fiu.edu. 


\section{FLORIDA INTERNATIONAL UNIVERSITY}

Miami, Florida

ESSAYS IN ECONOMIC GROWTH, POLITICAL ECONOMY AND INSTITUTIONS

A dissertation submitted in partial fulfillment of the

requirements for the degree of

DOCTOR OF PHILOSOPHY

in

ECONOMICS

by

Ece Handan Guleryuz

2012 
To: Dean Kenneth G. Furton

College of Arts and Sciences

This dissertation, written by Ece Handan Guleryuz, and entitled Essays in Economic Growth, Political Economy and Institutions, having been approved in respect to style and intellectual content, is referred to you for judgment.

We have read this dissertation and recommend that it be approved.

Peter Thompson

Sheng Guo

Sneh Gulati

Cem Karayalcin, Major Professor

Date of Defense: September 10, 2012

The dissertation of Ece Handan Guleryuz is approved.

$\begin{array}{r}\begin{array}{r}\text { Dean Kenneth G. Furton } \\ \text { College of Arts and Sciences }\end{array} \\ \hline \begin{array}{r}\text { Dean Lakshmi N. Reddi } \\ \text { University Graduate School }\end{array}\end{array}$

Florida International University, 2012 


\section{ACKNOWLEDGMENTS}

I wish to thank the members of my committee, Dr. Cem Karayalcin, Dr. Peter Thompson, Dr. Sheng Guo, and Dr. Sneh Gulati, for their guidance, encouragement, and patience in every important step of the Ph.D. Program. Their support and insightful comments have been very helpful in the completion of this dissertation. 


\section{ABSTRACT OF THE DISSERTATION \\ ESSAYS IN ECONOMIC GROWTH, POLITICAL ECONOMY AND INSTITUTIONS}

by

Ece Handan Guleryuz

Florida International University, 2012

Miami, Florida

Professor Cem Karayalcin, Major Professor

This dissertation analyzes the effects of political and economic institutions on economic development and growth.

The first essay develops an overlapping-generations political economy model to analyze the incentives of various social groups to finance human capital accumulation through public education expenditures. The contribution of this study to the literature is that it helps explain the observed differences in the economic growth performance of natural resource-abundant countries. The results suggest that the preferred tax rates of the manufacturers on one hand and the political coalition of manufacturers and landowners, on the other hand, are equal to the socially optimal tax rate. However, we show that owners of natural resources prefer an excessively high tax rate, which suppresses aggregate output to a suboptimal level.

The second essay examines the relationship between the political influence of different social classes and public education spending in panel data estimation. The novel contribution of this paper to the literature is that I proxy the political power and influence of the natural resource owners, manufacturers, and landowners with macroeconomic indicators. The motivation behind this modeling choice is to substantiate the definition of 
the political power of social classes with economic fundamentals. I use different governance indicators in the estimations to find out how different institutions mediate the overall impact of the political influence of various social classes on public education spending. The results suggest that political stability and absence of violence and rule of law are the important governance indicators.

The third essay develops a counter argument to Acemoglu et al. (2010) where the thesis is that French institutions and economic reforms fostered economic progress in those German regions invaded by the Napoleonic armies. By providing historical data on urbanization rates used as proxies for economic growth, I demonstrate that similar different rates of economic growth were observed in the regions of France in the postNapoleonic period as well. The existence of different economic growth rates makes it hard to argue that the differences in economic performance in the German regions that were invaded by the French and those that were spared a similar fate follow from regional differences in economic institutions. 


\section{TABLE OF CONTENTS}

CHAPTER

PAGE

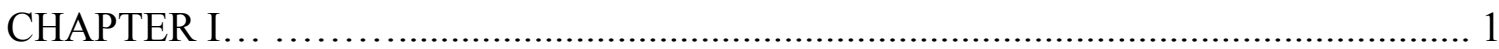

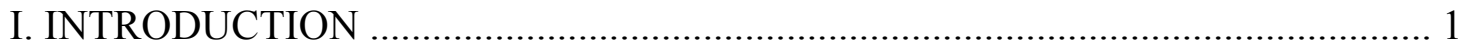

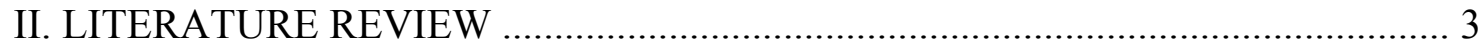

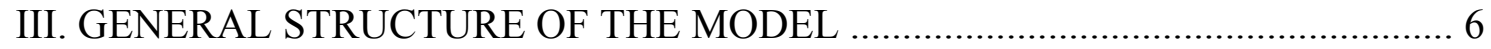

Natural Resource Sector …………………………................................. 7

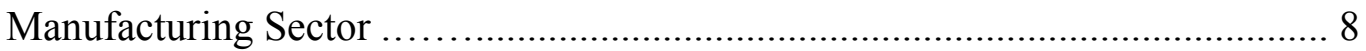

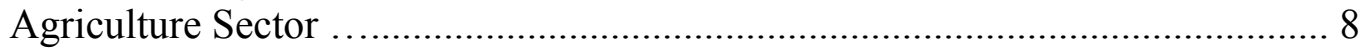

Individuals, Preferences and Income............................................................. 9

Human Capital Accumulation and the Political Mechanism .............................. 11

IV. DIFFERENT POLITICAL AUTHORITY FORMATIONS .................................. 12

Efficient Human Capital Accumulation Policies and Aggregate Output ........... 12

Manufacturers Have the Political Power …………………………………..... 16

Landowners Have the Political Power ........................................................... 19

Natural Resource Owners Have the Political Power ………………………....... 21

Political Coalition of Manufacturers and Natural Resource Owners ............... 23

Political Coalition of Manufacturers and Landowners ................................... 24

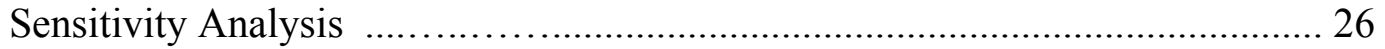

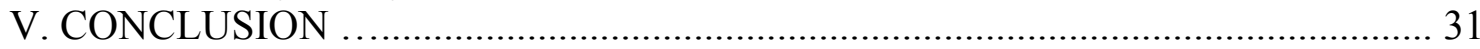

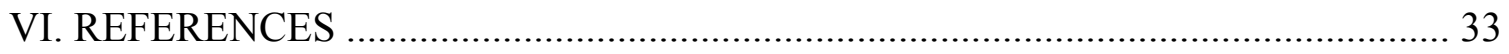

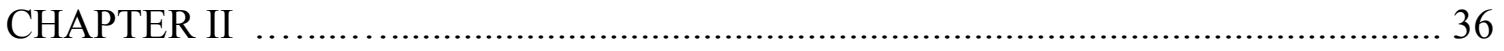

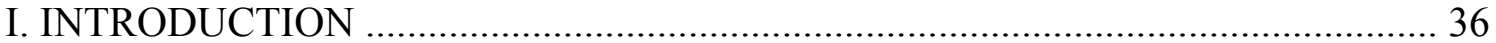

II. ECONOMETRIC STRATEGY AND DATA DETAILS ……………………........ 38

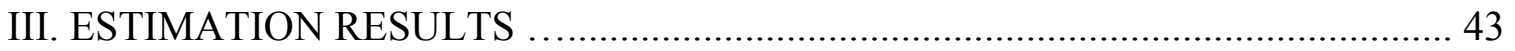

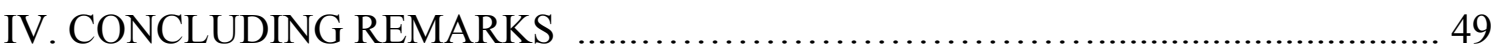

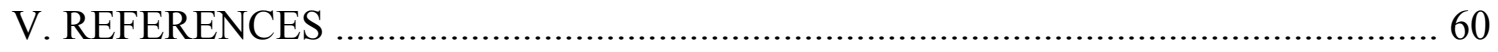

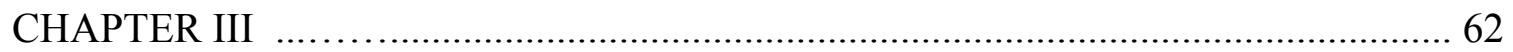

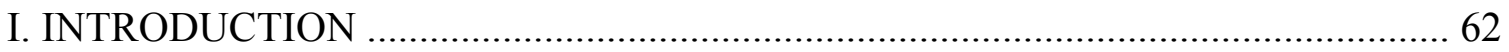

II. HISTORICAL OVERVIEW OF THE FRENCH REVOLUTION ............................ 64

III. ACEMOGLU, CANTONI, JOHNSON, AND ROBINSON (2011) PAPER .......... 66

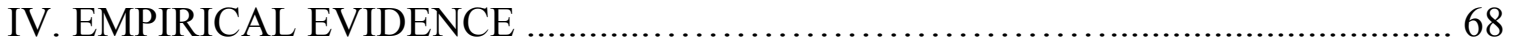

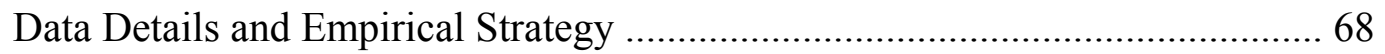

Classical Hypothesis Testing ………………………................................... 70

Difference-in-differences Estimation.............................................................. 71

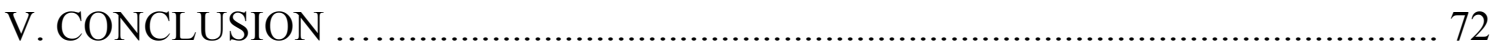

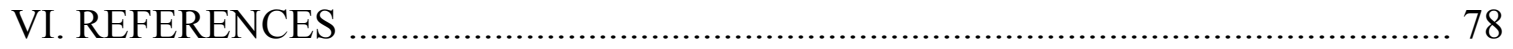

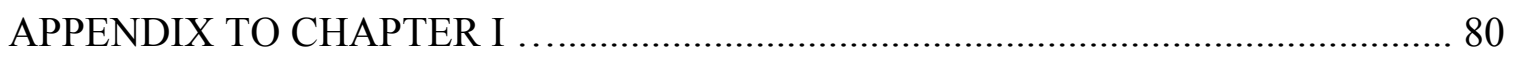

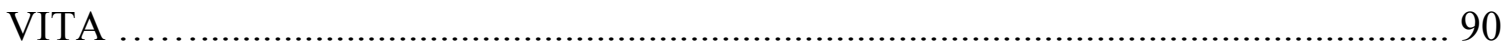




\section{LIST OF TABLES}

TABLE

PAGE

1. Simulation Results under Different Political Coalitions .........................................27

2. Sensitivity Analysis under Manufacturers' Political Authority .................................27

3. Sensitivity Analysis under Resource Owners' Political Authority .............................29

4. Sensitivity Analysis under Manufacturers-Resource Owners Coalition ......................30

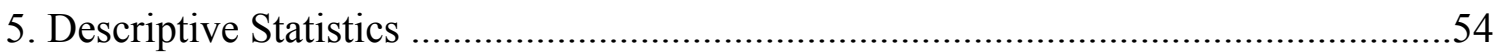

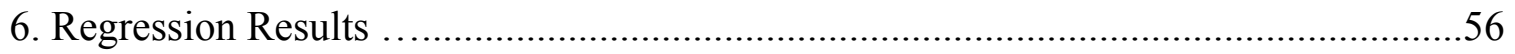

7. Regression Results: Middle Income Countries .....................................................58

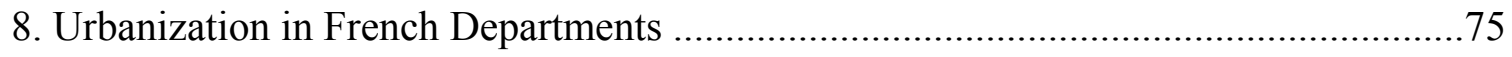

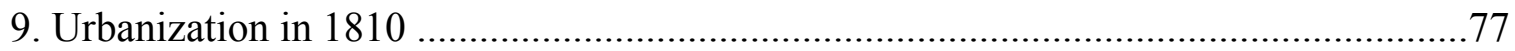

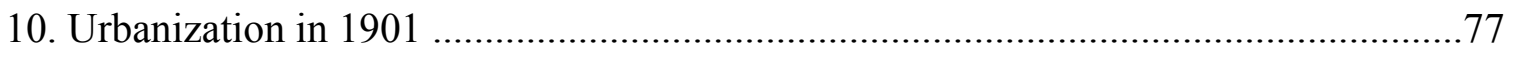

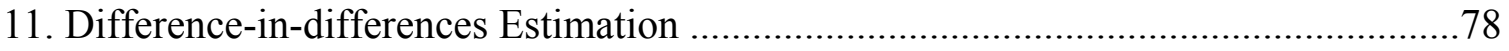




\section{CHAPTER I}

\section{INTRODUCTION}

The last three decades have witnessed the highly divergent economic performance of several natural resource abundant countries. During the period $1975-2007$, the average growth rates of GDP per capita of Norway and Botswana were $2.77 \%$ and $4.46 \%$ respectively. On the other hand, in the same period, resource-rich Venezuela and Zambia experienced average rates of growth of $-0.26 \%$ and $-0.30 \%$ GDP per capita (Penn World Table, 2009). Hence, rather paradoxically, natural resource-abundant countries are among both the richest and the poorest countries in the world. Some resource-abundant countries have achieved high and sustainable economic growth; while others have ended up as economic growth disasters. ${ }^{1}$

Thus, consider, for instance, Norway, one of the richest natural resource-abundant countries. In the late 1960s, after it discovered oil, Norway used its oil revenues to finance the education of a highly skilled labor force and high-technology industries (Gerlagh and Papyrakis, 2004). On the other hand, Venezuela is usually cited as the contrasting example to Norway. As a result of widespread corruption and the strong impact of the landowners on government policies, Venezuela has turned out to be an economic failure.

The purpose of my study is to shed new light on the nexus between natural resource abundance and human capital accumulation from a political economy perspective. The present paper suggests that the effect of natural resource abundance on human capital

\footnotetext{
${ }^{1}$ See van der Ploeg (2009) for a detailed overview.
} 
accumulation is at least partially determined by the identity of the social groups that hold political power and the level of economic benefits these groups derive from a more educated labor force in a multi-sector economy. Here human capital constitutes the engine of economic growth and is complementary to both natural resources and physical capital. One consequence of this assumption is that not only the manufacturers but also the owners of natural resources support human capital accumulation financed through public education expenditures.

If the manufacturers have the political power or join in a political coalition with the landowners, the implemented tax rates are equal to the socially optimal tax rate. If the landowners are in power, they prefer a level of expenditure on public education expenditure that is lower than the efficient level by choosing a tax rate smaller than the socially optimal one. There are two opposing factors affecting the landowners' decision. Firstly, as the complementarity between human capital and land is low, an increase in human capital reduces the return to land as labor migrates from agriculture to the manufacturing and natural resources sectors. Secondly, since human capital accumulation increases the marginal return to labor, landowners also obtain an increase in their wage income with a rise in human capital accumulation. Whether landowners support financing of public education depends on the relative strengths of these two effects. When natural resource owners have the political authority, they prefer a tax rate higher than the socially optimal tax rate. The natural resource owners' distortionary tax policy decreases the marginal return to physical capital because of the labor transfer from the manufacturing sector to the natural resources sector. 
In short, the paper offers an alternative explanation as to why some natural resource abundant countries, such as Norway, succeed in attaining high levels of sustained economic growth, while others, such as Nigeria, fail to do so. The suggestion here is that in those natural resource abundant countries where manufacturers have a certain degree of political power, the tax policy chosen supports human capital accumulation through public education expenditures. On the other hand, in those natural resource abundant countries where political power is in the hands of landowners the support for public education is not as strong. Wherever the natural resource owners hold the political authority the tendency is to implement a distortionary tax policy designed to raise their returns from the natural resource stock as much as possible.

The theoretical analysis in this paper thus presents a three-class economic conflict among the manufacturers, natural resource owners and landowners. Here we differ from other studies proposing mainly a two-class conflict between the manufacturers and landowners (Galor, Moav and Vollrath, 2009), or between the landowners and workers.

The paper is organized as follows. Section 2 discusses the related literature this paper stands on. Section 3 presents the general theoretical model, and Section 4 develops various political economy implications about human capital accumulation. Finally, Section 5 provides the conclusion.

\section{LITERATURE REVIEW}

The present paper mainly stands at the nexus of two strands in the literature. One of these attempts is to link economic growth and institutions, while the other looks at the 
connection between natural resource abundance and economic growth. Both of these literatures are vast and it is beyond the scope of this paper to discuss them in detail. I will, therefore, focus on certain papers in the areas of natural resource abundance, human capital accumulation, economic growth and political economy that are closely related to the issues addressed in this paper.

The relationship between economic growth and political decisions is emphasized in North's seminal work. North (1981) argues that the political elite may not adopt growthenhancing policies, such as those promoting human capital accumulation, if these policies do not maximize the revenues of the political elite. The view of the policies adopted by the political elite preventing economic growth because of potential economic losses is consistent with the theory proposed in the current paper. In their 2000 and 2006 papers where they analyze the political roots of economic backwardness, Acemoglu and Robinson argue that the social groups which have political power, particularly landlords, may prevent technological developments and the adoption of growth-enhancing institutions if they see these as a threat to their political power and economic rents. In a related work, Bourguignon and Verdier (2000) analyze the circumstances under which an educated oligarchy invests in the human capital accumulation of the poor through education and how this affects democratization movements in a dynamic political economy model. I abstract from the dynamics of political power and the election mechanisms such as single-peaked preferences, median voter theorem, and strategic voting in sequential elections in this paper. Glaeser et al. (2004) focus on the relationship between human capital accumulation and institutional development, and find that human capital formation leads to the emergence of growth-enhancing political institutions. 
The social class conflicts analyzed in the political economy setup here is derived from Galor, Moav and Vollrath (2009) and on the analysis done in Acemoglu and Robinson's (2006) influential book "Economic Origins of Dictatorship and Democracy." In particular, the theoretical model analyzed in my paper follows from the multi-sector, multi-class model in Galor et al. (2009), which argues that inequality in the distribution of landownership negatively affects human capital accumulation. Unlike this latter work, my paper analyzes the effect of social class conflicts and the political power struggle on human capital accumulation policies in an economy that is abundant in natural resources.

Certain aspects of the relationship between natural resource abundance and economic growth, commonly referred to as the "resource curse," have been widely studied in literature. Torvik (2009) and van der Ploeg (2009) provide good overviews of the recent empirical and theoretical research on the resource curse. Nevertheless, there is still limited research done on the nexus between natural resource abundance and human capital accumulation, and most of these studies are empirical. Using a model with two sectors that incorporates the effects of both endogenous growth and reallocation of resources, Bravo-Ortega and De Gregorio (2002) argue that a high level of human capital can alleviate the negative effect of natural resources on economic growth rate. They find support for their argument empirically using panel data for the period 1970-1990. Birdsall et al. (2001) and Gylfason (2001) find a negative correlation between resource abundance and human capital accumulation. In contrast, Stijns (2006) finds a positive relationship between human capital formation and resource abundance in an empirical study. He argues that Birdsall et al. (2001) and Gylfason (2001) reach biased results because of the questionable natural resource abundance indicators they used. Regarding 
these conflicting empirical results, van der Ploeg (2009) states that the use of certain variables can create serious endogeneity problems.

\section{GENERAL STRUCTURE OF THE MODEL}

The theoretical setup is an overlapping-generations, small, open, natural resource abundant economy in the process of development. Natural resource abundance of a country is defined as the higher amount of subsoil resources compared to other countries. The prices of goods are normalized to one for simplicity. A single homogeneous good used for consumption and investment is produced in a manufacturing sector and an agriculture sector every period. There is also a natural resource sector which functions as an intermediate industry producing an input used in the manufacturing sector. The main inputs used to produce the final output are natural resources, physical capital, human capital, land and unskilled (raw) labor. In the economy under study, human capital is assumed to be the engine of modern economic growth. In every period, the stock of human capital is determined by the aggregate public investment in education in the preceding period.

In period $t$, the final output in the economy, $Q_{t}$, is defined by the aggregate output produced in the manufacturing sector, $Q_{t}^{M}$, and in the agriculture sector, $Q_{t}^{A}$,

$Q_{t}=Q_{t}^{M}+Q_{t}^{A}$ 
Natural Resource Sector

The production in the natural resource sector takes place within a period according to a neoclassical, constant-returns-to-scale, Cobb-Douglas production technology using natural resources and human capital as inputs. We define the output produced at time $t$, $Q_{t}^{N}$, with the following equation,

$Q_{t}^{N}=F^{N}\left(N_{t}, H_{t}^{N}\right)=N_{t}^{\beta} H_{t}^{N(1-\beta)}=H_{t}^{N} n_{t}^{\beta}, n_{t} \equiv N_{t} / H_{t}^{N}, \beta \in(0,1)$

where $N_{t}$ is the natural resources stock (which is mainly unprocessed subsoil wealth such as oil, minerals etc.) and $H_{t}^{N}$ is the quantity of human capital (measured in efficiency units) employed in production at time $t$. In the natural resource sector, producers operate in a perfectly competitive environment. Hence, the wage rate per worker, $w_{t}^{N}$, and the rate of return to natural resources stock, $v_{t}$, in period $t$ are expressed as the following:

$w_{t}^{N}=F_{H^{N}}^{N}\left(N_{t}, H_{t}^{N}\right)$

$v_{t}=F_{N}^{N}\left(N_{t}, H_{t}^{N}\right)$

Moreover, the labor share in the natural resource sector is given by

$s_{t}^{H^{N}}=H_{t}^{N} w_{t}^{N}$

The share of natural resources in the natural resource sector is

$s_{t}^{N}=\beta Q_{t}^{N}$ 


\section{Manufacturing Sector}

The production in the manufacturing sector occurs within a period according to a neoclassical, constant-returns-to-scale, Cobb-Douglas production technology using physical capital, $K_{t}$, human capital, $H_{t}^{M}$ (measured in efficiency units), and the output of the natural resource sector, $Q_{t}^{N}$ (from now on called the resource input), employed in production at time $t$. The output produced at time $t, Q_{t}^{M}$, is

$Q_{t}^{M}=F^{M}\left(K_{t}, H_{t}^{M}, Q_{t}^{N}\right)=K_{t}^{\alpha} H_{t}^{M(\theta)} Q_{t}^{N(1-\alpha-\theta)} ; \quad \alpha \in(0,1), \theta \in(0,1)$

Physical capital depreciates fully after one period. In the manufacturing sector, producers operate in a perfectly competitive environment. The rate of return to physical capital, $R_{t}$, the wage rate per worker, $w_{t}^{M}$, and the rate of return to the resource input, $\rho_{t}$, in period $t$, factor prices can be defined as:

$$
\begin{aligned}
& R_{t}=F_{K}^{M}\left(K_{t}, H_{t}^{M}, Q_{t}^{N}\right) \\
& w_{t}^{M}=F_{H^{M}}^{M}\left(K_{t}, H_{t}^{M}, Q_{t}^{N}\right) \\
& \rho_{t}=F_{Q^{N}}^{M}\left(K_{t}, H_{t}^{M}, Q_{t}^{N}\right)
\end{aligned}
$$

\section{Agriculture Sector}

In the agriculture sector, the Cobb-Douglas production technology uses land, $Z_{t}$, and raw labor, $L_{t}$, as inputs. Production occurs in a perfectly competitive environment as in the natural resource and manufacturing sectors. The output produced at time $t, Q_{t}^{A}$, is

$$
Q_{t}^{A}=F^{A}\left(Z_{t}, L_{t}\right)=Z_{t}^{\gamma} L_{t}^{1-\gamma}=L_{t} z_{t}^{\gamma} ; z_{t} \equiv Z_{t} / L_{t}, \gamma \in(0,1)
$$


The rate of return to land, $x_{t}$, and the wage rate per worker, $w_{t}^{A}$ can be defined as

$x_{t}=F_{Z}^{A}\left(Z_{t}, L_{t}\right)$

$w_{t}^{A}=F_{L}^{A}\left(Z_{t}, L_{t}\right)$

Individuals, Preferences and Income

A generation is a continuum of individuals of measure 1 born in every period. Both within and across generations, individuals are identical regarding their preferences and innate abilities. Nevertheless, they may differ from each other in terms of their wealth. Each individual lives for two periods, and has a single parent and a single child. The preferences of an individual $i$ of generation $t$ are defined over the second period consumption, $c_{t+1}^{i}$, and a transfer to the offspring, $b_{t+1}^{i}$, with a log-linear utility function

$U_{t}^{i}=(1-a) \ln c_{t+1}^{i}+a \ln b_{t+1}^{i} \quad, \quad a \in(0,1)$

Individuals acquire human capital in the first period of their lives. In the second period they join the labor-force, earn a wage income, and the returns to natural resources, physical capital, and land. They allocate their second period income between consumption and an income transfer to their children. Hence, an individual $i$ born in period $t$ is given an income transfer, $b_{t}^{i}$, in the first period of life.

Now, an individual $i$ born in period $t$ earns the competitive market wage $w_{t+1}$ by joining the labor-force; she may also obtain income from the return on natural resources ownership, $m^{i} v_{t+1}$, where $m^{i}$ is agent $i$ 's endowment of natural resources, from physical capital ownership, $\left(1-\tau_{t}\right) b_{t}^{i} R_{t+1}$, and from the return on land ownership, $s^{i} x_{t+1}$, where 
$s^{i}$ is the quantity of land owned by agent $i$. In the current economic framework, workers do not own any natural resources, physical capital, or land. In the second period natural resource owners leave all the natural resources, and landowners leave all the land to their offspring. These assumptions preserve the social class structure over time.

Now, we can define the individual's second period income as the following,

$y_{t+1}^{i}=w_{t+1}+\left(1-\tau_{t}\right) b_{t}^{i} R_{t+1}+m^{i} v_{t+1}+s^{i} x_{t+1}$

where $m^{i}=N_{t} / \sigma$, and $N_{t}$ is the total stock of natural resources, $\sigma \in(0,1)$ is the fraction of natural resource owners in the economy among whom the natural resources stock is shared equally. In addition, $s^{i}=Z_{t} / \mu$, where $Z_{t}$ is the total amount of land, and $\mu \epsilon(0,1)$ is the fraction of landowners in the economy who equally share all the land among themselves. ${ }^{2}$

The individual $i$ born in period $t$ allocates second period income between consumption, $c_{t+1}^{i}$, and income transfers to the offspring, $b_{t+1}^{i}$, in order to maximize his utility subject to the second period budget constraint, so

$c_{t+1}^{i}+b_{t+1}^{i} \leq y_{t+1}^{i}$

The optimal transfer and consumption of the individual $i$ born in period $t$ can be shown to be the following:

$$
\begin{aligned}
& b_{t+1}^{i}=a y_{t+1}^{i} \\
& c_{t+1}^{i}=(1-a) y_{t+1}^{i}
\end{aligned}
$$

\footnotetext{
${ }^{2}$ Note that $m^{i}$ and $s^{i}$ may be equal to zero depending on the social group that the individual belongs to.
} 
Human Capital Accumulation and the Political Mechanism

As mentioned above, individuals spend the first period of their two-period lives to acquire human capital. The political authority invests in human capital through public education. The amount of human capital accumulated increases with the real resources invested in public education. Here human capital accumulation is a strictly increasing, strictly concave function of real expenditures, $e_{t}$, on the education of a member of generation $t$

$h_{t+1}=h\left(e_{t}\right)$,

where $h_{t+1}$ is the human capital of each individual of generation $t$ in period $t+1$, $h(0)=1, \lim _{e_{t} \rightarrow 0^{+}} h^{\prime}\left(e_{t}\right)=\infty, \lim _{e_{t} \rightarrow \infty} h^{\prime}\left(e_{t}\right)=0$.

Thus, even if the real expenditure on public education is zero, individuals own one efficiency unit of human capital that forms the basic skills required for the natural resources sector and manufacturing sector to operate in every period.

In this economic environment, there are four distinct groups of agents: Natural resource owners, manufacturers, landowners and workers. The across-group heterogeneity is mainly formed by the distinction that in period $t$ natural resource owners, manufacturers, landowners and workers get their incomes from the respective resources they own. This argument follows from a similar analysis in Acemoglu and Robinson (2006, Chapter 8 and Chapter 9). Because of the existence of heterogeneous social groups and their different economic incentives, policies for human capital accumulation change as the political authority changes hands among these groups. The social groups holding the political power have ultimate control on public education policies. 
In order to finance public education for human capital accumulation, the current political authority collects a fraction $\tau_{t}$ of the income each group receives. The primary motivation here is that when a social group has political power, it chooses to invest in human capital accumulation if the benefits the group's agents receive from a more educated labor force exceed the costs of financing public education by paying taxes from their bequest incomes and intergenerational income transfers.

The main concentration of this paper is on the economic effects various social groups and political authorities have on human capital accumulation policies, but not on the political process by which the political authorities and coalitions come about. Therefore, note that the social group which holds the political authority or shares the political power with another group in a coalition is determined historically, and so this side of the political mechanism is exogenous in the theoretical model. I also ignore within social group conflicts in the analysis.

\section{DIFFERENT POLITICAL AUTHORITY FORMATIONS}

\section{Efficient Human Capital Accumulation Policies and Aggregate Output}

As it follows from equation (12), the aggregate level of intergenerational transfers in period $t$ is a fraction $a$ of the aggregate income $Q_{t}$. In order to finance public education, the political authority collects a fraction $\tau_{t}$ of income transfer as the tax revenues, so, to be saved for future consumption a fraction $1-\tau_{t}$ of the transfers is left. Now, the aggregate intergenerational transfers can be written as the following 
$a Q_{t}=b$

where $b$ is defined as the total amount of bequest incomes. Then, the physical capital stock in period $t+1$ can be defined as,

$K_{t+1}=\left(1-\tau_{t}\right) a Q_{t}=\left(1-\tau_{t}\right) b$

and the education expenditure per young individual in period $t, e_{t}$, is

$e_{t}=\tau_{t} a Q_{t}=\tau_{t} b$

Let us define $\delta_{t+1}^{N}, \delta_{t+1}^{M}, \delta_{t+1}^{A}$ to be the numbers (and so fractions) of workers employed in the natural resources sector, in the manufacturing sector, and in the agriculture sector respectively. Then, the stock of human capital employed in natural resource sector in period $t+1, H_{t+1}^{N}$, can be defined as,

$H_{t+1}^{N}=\delta_{t+1}^{N} h\left(e_{t}\right)=\delta_{t+1}^{N} h\left(\tau_{t} a Q_{t}\right)$

The amount of natural resource stock is fixed over time at a level $N>0$, so output in the natural resource sector in period $t+1$ is,

$Q_{t+1}^{N}=N^{\beta} H_{t+1}^{N(1-\beta)}=N^{\beta}\left[\delta_{t+1}^{N} h\left(\tau_{t} a Q_{t}\right)\right]^{1-\beta} \equiv Q^{N}\left(Q_{t}, \tau_{t}, \delta_{t+1}^{N}, N\right)$

Similar to the case in natural resource sector, the stock of human capital employed in manufacturing sector in period $t+1, H_{t+1}^{M}$, can be written as

$H_{t+1}^{M}=\delta_{t+1}^{M} h\left(e_{t}\right)=\delta_{t+1}^{M} h\left(\tau_{t} a Q_{t}\right)$

then output produced in the manufacturing sector can be written as

$Q_{t+1}^{M}=K_{t+1}^{\alpha} H_{t+1}^{M(\theta)} Q_{t+1}^{N(1-\alpha-\theta)}$ 
$Q_{t+1}^{M}=\left[\left(1-\tau_{t}\right) a Q_{t}\right]^{\alpha}\left[\delta_{t+1}^{M} h\left(\tau_{t} a Q_{t}\right)\right]^{\theta}\left[N^{\beta}\left[\delta_{t+1}^{N} h\left(\tau_{t} a Q_{t}\right)\right]^{1-\beta}\right]^{(1-\alpha-\theta)}$

$Q_{t+1}^{M} \equiv Q^{M}\left(Q_{t}, \tau_{t}, \delta_{t+1}^{N}, \delta_{t+1}^{M}, N\right)$

In agriculture sector the labor supply $L_{t+1}\left(L_{t+1}=\delta_{t+1}^{A}\right)$ can also be expressed as $\left(1-\delta_{t+1}^{N}-\delta_{t+1}^{M}\right)$, and the land size is constant over time at a level $Z>0$. Thus, output in agriculture sector in period $t+1$ can be written as

$Q_{t+1}^{A}=Z^{\gamma} L_{t+1}^{1-\gamma}=Z^{\gamma}\left(\delta_{t+1}^{A}\right)^{1-\gamma}=Z^{\gamma}\left(1-\delta_{t+1}^{N}-\delta_{t+1}^{M}\right)^{1-\gamma} \equiv Q^{A}\left(\delta_{t+1}^{N}, \delta_{t+1}^{M}, Z\right)$

Individuals are perfectly mobile between the manufacturing sector, natural resources sector and agriculture sector. Thus, they can earn the wage incomes $h_{t+1} w_{t+1}^{M}, h_{t+1} w_{t+1}^{N}$ or the wage $w_{t+1}^{A}$ by supplying $h_{t+1}$ efficiency units of labor to the manufacturing sector or natural resources sector, or one unit of labor to the agriculture sector respectively. The number of workers in the manufacturing sector, $\delta_{t+1}^{M}$, and in natural resource sector, $\delta_{t+1}^{N}$, equalize the marginal products of workers in the three sectors under each political coalition. Therefore,

$h_{t+1} w_{t+1}^{M}=h_{t+1} w_{t+1}^{N}=w_{t+1}^{A}=w_{t+1}$

The fractions of workers employed by the manufacturing sector, natural resource sector and agriculture sector in period $t+1$, are uniquely determined with respect to the tax policy the political authority imposes under each political coalition:

$\delta_{t+1}^{M}=\delta^{M}\left(Q_{t}, \tau_{t}^{j}, N, Z\right) ; \delta_{t+1}^{N}=\delta^{N}\left(Q_{t}, \tau_{t}^{j}, N, Z\right) ; \delta_{t+1}^{A}=\delta^{A}\left(Q_{t} \tau_{t}^{j}, N, Z\right)(23)$ 
In equation (23), $\tau_{t}{ }^{j}$ refers to the tax rates imposed by different political coalitions. Further, given the natural resource stock, $N$, and agricultural land size, $Z$, in period $t+1$ prices are uniquely determined by $Q_{t}$ and $\tau_{t}{ }^{j}$ under each political coalition:

$$
\begin{aligned}
& w_{t+1}=w\left(Q_{t} \tau_{t}^{j}, N, Z\right) \\
& R_{t+1}=R\left(Q_{t}, \tau_{t}^{j}, N, Z\right) \\
& v_{t+1}=v\left(Q_{t}, \tau_{t}^{j}, N, Z\right) \\
& x_{t+1}=x\left(Q_{t}, \tau_{t}^{j}, N, Z\right) \\
& \rho_{t+1}=\rho\left(Q_{t}, \tau_{t}^{j}, N, Z\right)
\end{aligned}
$$

Hence, the prices given in (24), and the employment shares given in (23) are moving endogenously with the specific tax policy each political coalition implements.

The model predicts that given the aggregate income in period $t, a Q_{t}$, the level of natural resources stock, $N$, and the amount of land, $Z$, there exists a unique tax rate, $\tau_{t}^{*}$, which maximizes the aggregate output, $Q_{t+1}$, in period $t+1$.

$\tau_{t}^{*} \equiv \operatorname{argmax} Q_{t+1}$

Furthermore, the numbers of workers employed in the manufacturing sector, $\delta^{M *}\left(Q_{t}, \tau_{t}^{*}, N, Z\right)$, and in the natural resources sector, $\delta^{N *}\left(Q_{t}, \tau_{t}^{*}, N, Z\right)$, in period $t+1$ are uniquely determined with respect to $\tau_{t}^{*}$, satisfying the socially optimal labor distribution in the three sectors. Figure 1 demonstrates the aggregate output according to the human capital accumulation policy (tax policy) of the political authority. As depicted 
in Figure 1 , the socially optimal tax rate, $\tau_{t}^{*}$, achieves the maximum aggregate output and efficient public education at the point B.

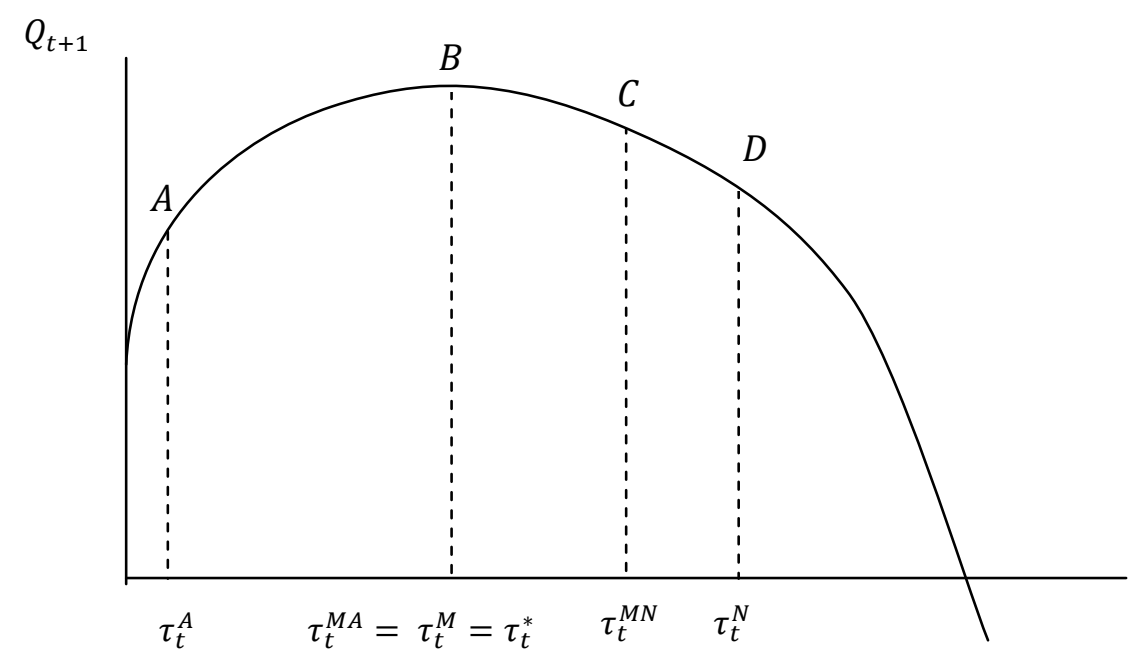

Figure 1. The aggregate output with various tax policies under different political authority formations

Manufacturers Have the Political Power

Manufacturers comprise a fraction $\vartheta \in(0,1)$ of all individuals in the society. They do not own any natural resources and any land, so we can write the second period income function of a manufacturer as the following:

$y_{t+1}^{M}=w_{t+1}+\left(1-\tau_{t}^{M}\right) b_{t}^{M} R_{t+1}$

$y_{t+1}^{M}=w\left(Q_{t}, \tau_{t}^{M}, N, Z\right)+\left(1-\tau_{t}^{M}\right) b_{t}^{M} R\left(Q_{t}, \tau_{t}^{M}, N, Z\right)$

where $w\left(Q_{t}, \tau_{t}^{M}, N, Z\right)$ is the wage income, $b_{t}^{M}$ is the portion of total bequest income that a manufacturer gets, and $R\left(Q_{t}, \tau_{t}^{M}, N, Z\right)$ is the rate of return to physical capital. When manufacturers hold the political power their main objective is to reach the highest level of 
their income in the second period. ${ }^{3}$ Thus, they choose such a tax rate, $\tau_{t}^{M}$, that maximizes each manufacturer's income function in period $t+1$. Since manufacturers earn their income from wage and bequest transfers of physical capital ownership, $\tau_{t}^{M}$ also maximizes the manufacturing sector output. Therefore, manufacturers collect a fraction $\tau_{t}^{M}$ of intergenerational income transfers (bequest incomes) as tax revenues in order to finance public education, so a fraction $1-\tau_{t}^{M}$ of the transfers is saved for future consumption. Since human capital is complementary with physical capital in the manufacturing sector, manufacturers get economic benefits from a more educated labor force, so they are in favor of human capital accumulation. ${ }^{4}$

Proposition 1 When the manufacturers hold political power they support human capital accumulation through public education expenditure with a preferred tax rate $\tau_{t}^{M} .{ }^{5}$ Hence, $\tau_{t}^{M}=\operatorname{argmax}_{t+1}^{M}$

In this subsection, it is demonstrated that the preferred tax rate from the point of view of the manufacturers, $\tau_{t}^{M}$, is equal to the socially optimal tax rate that maximizes the aggregate output, $\tau_{t}^{*}$. Hence, as the manufacturers have the political power, the tax rate chosen to be implemented by them $\left(\tau_{t}^{M}\right)$ is identical to the tax rate which achieves the efficient level of investment in public education $\left(\tau_{t}^{*}\right)$. In addition to this, the evolution of the manufacturing sector output, $Q_{t+1}^{M}$, according to the tax policy implemented by the political authority of manufacturers will be identical to the graph of the aggregate output

\footnotetext{
${ }^{3}$ This is equivalent to the utility maximization subject to the second period budget constraint explained in Section 3.4.

${ }^{4}$ For this statement, the calibration explanations and results can be seen in Section 4.7.

${ }^{5}$ A demonstration is provided in Section A.2 in the Appendix.
} 
depicted in Figure 1. Therefore, under the political authority of manufacturers the maximized aggregate output and the efficient human capital accumulation level will be achieved again at point $\mathrm{B}$.

Lemma 1 Suppose that $\tau_{t}^{M}$ is the tax rate preferred by manufacturers and maximizes the output of the manufacturing sector in period $t+1$, so

$\tau_{t}^{M} \equiv \operatorname{argmax} Q_{t+1}^{M}=\operatorname{argmax} Q^{M}\left(Q_{t}, \tau_{t}, \delta_{t+1}^{N}, \delta_{t+1}^{M}, N\right)$

This tax rate is also equal to the socially optimal tax rate, $\tau_{t}^{*}$.

Proof. As follows from (1), Appendix A.1 and from the envelope theorem

$\partial Q_{t+1} / \partial \tau_{t}=\partial Q^{M}\left(Q_{t}, \tau_{t}, \delta_{t+1}^{N}, \delta_{t+1}^{M}, N\right) / \partial \tau_{t}$

Moreover, since $\tau_{t}^{*}=\operatorname{argmax} Q_{t+1}$, then $\partial Q^{M}\left(Q_{t}, \tau_{t}{ }^{*}, \delta_{t+1}^{N}, \delta_{t+1}^{M}, N\right) / \partial \tau_{t}=0$, and so it follows from (20) that,

$\delta_{t+1}^{M} w_{t+1}^{M} h^{\prime}\left(\tau_{t}^{*} a Q_{t}\right)+\rho_{t+1} \delta_{t+1}^{N} w_{t+1}^{N} h^{\prime}\left(\tau_{t}^{*} a Q_{t}\right)=R_{t+1}$

Therefore,

$\tau_{t}^{*}=\operatorname{argmax} Q^{M}\left(Q_{t}, \tau_{t}, \delta_{t+1}^{N}, \delta_{t+1}^{M}, N\right)=$

$\operatorname{argmax}\left[\left(1-\tau_{t}\right) a Q_{t}\right]^{\alpha}\left[\delta_{t+1}^{M} h\left(\tau_{t} a Q_{t}\right)\right]^{\theta}\left[N^{\beta}\left[\delta_{t+1}^{N} h\left(\tau_{t} a Q_{t}\right)\right]^{1-\beta}\right]^{(1-\alpha-\theta)}$

Hence, $\tau_{t}^{*}=\tau_{t}^{M}$.

Thus, under the political authority of manufacturers the socially optimal level of the aggregate output is also achieved.

Now also, following from (6), (20) and Section A.2 in the Appendix; $\left(1-\tau_{t}\right) a Q_{t} R_{t+1}=$ $\alpha Q_{t+1}^{M}$ 
Then, $\left(1-\tau_{t}\right) R_{t+1}=\alpha Q_{t+1}^{M} /\left(a Q_{t}\right)$, and so $\tau_{t}^{*}=\operatorname{argmax}\left(1-\tau_{t}\right) R_{t+1}$

Hence, $\tau_{t}^{*}$ also maximizes the after tax returns from physical capital ownership.

\section{Landowners Have the Political Power}

Landowners set up a fraction $\mu \epsilon(0,1)$ of all individuals in the total population, and they equally share the entire land in the economy in all periods. Landowners do not hold physical capital and they do not own any natural resources. Then, we can write the second period income function of a landowner as;

$y_{t+1}^{A}=w_{t+1}+s^{A} x_{t+1}$

where $s^{A}$ is the return on land ownership. ${ }^{6}$ When the landowners have the ultimate political power they will implement a tax rate that maximizes the income of a landowner in period $t+1$. Landowners do not obtain any earnings from the ownership of physical capital and natural resources with which human capital is used in the industrial production. Therefore, an increase in human capital will reduce the return to land as a consequence of labor migration from the agriculture sector to the natural resources and manufacturing sectors, so depending on the effect of returns on land ownership landowners want to retain as much unskilled labor as they can on the land. On the other hand, following from (22) since human capital accumulation increases the marginal returns to labor in the manufacturing and natural resource sectors, and the marginal

\footnotetext{
${ }^{6}$ Landowners might get economic benefits from human capital accumulation due to physical capital and natural resource ownerships, labor supply to the manufacturing sector and natural resources sector, and the provision of public goods. Nevertheless, in the consideration of the landowners' income function in period these possibilities are excluded from the analysis.
} 
products of workers are equalized across the three sectors landowners also obtain an increase in their wage income with a rise in human capital accumulation. Under their political authority, these two opposing effects make the landowners prefer a tax rate, $\tau_{t}^{A}$, which is greater than zero but lower than the tax rate chosen by the manufacturers, $\tau_{t}^{M}$, and so lower than the socially optimal tax rate, $\tau_{t}^{*}$. Thus, the tax policy chosen by the landowners does not achieve the efficient public education investment level, and the aggregate output obtained under the political authority of landowners remains at a suboptimal level compared to the maximum level of aggregate output. ${ }^{7}$ The lower aggregate output and the tax policy preferred by the landowners can be shown with point A in Figure 1. Note in Section A.1 in the Appendix, the profit maximization condition of the manufacturers' second period income function is defined as,

$$
\begin{aligned}
& \left\{\left\{\left[(1-\alpha-\beta+\alpha \beta+\theta \beta) h^{\prime}\left(\tau_{t}^{M} a Q_{t}\right)\left[h\left(\tau_{t}^{M} a Q_{t}\right)\right]^{-1}\right]-\left[\alpha\left(1-\tau_{t}^{M}\right)^{-1}\right]+\right.\right. \\
& \theta \delta t+1 M-1 \partial \delta M Q t, \tau t M, N, Z \partial \tau t M+1-\beta 1-\alpha-\theta \delta t+1 N-1 \partial \delta N Q t, \tau t M, N, Z \partial \tau t M \\
& \theta \delta t+1 M-1+\alpha b t M a Q t-1-\theta \delta t+1 M-2 \partial \delta M Q t, \tau t M, N, Z \partial \tau t M=0
\end{aligned}
$$

The expression $\left[\alpha b_{t}^{M}\left(a Q_{t}\right)^{-1}\right]$ refers to the bequest incomes that the manufacturers earn from physical capital ownership. The landowners do not own physical capital, and so they do not obtain any earnings from capital ownership. Since human capital is complementary to physical capital making it more productive when used together,

\footnotetext{
${ }^{7}$ This statement is discussed in Section A.3 in the Appendix.
} 
employing more human capital in the manufacturing sector increases the returns to physical capital. Therefore, manufacturers will prefer a higher tax rate than the tax rate landowners prefer. Hence,

$$
\tau_{t}^{A}<\tau_{t}^{M}
$$

Natural Resource Owners Have the Political Power

The natural resource owners set up a fraction $\sigma \epsilon(0,1)$ among the total population. Natural resource owners equally own the entire natural resource stock, and they also obtain returns from physical capital ownership, but they do not own any land. Thus, we can define the second period income function of a natural resource owner as

$y_{t+1}^{N}=w_{t+1}+\left(1-\tau_{t}^{N}\right) b_{t}^{N} R_{t+1}+m^{N} v_{t+1}$

where $b_{t}^{N}$ is the portion of total bequest income that a natural resource owner gets, and $m^{N}$ is the endowment of natural resource stock a natural resource owner owns and $v_{t+1}$ is the rate of return to natural resources stock as defined in section 3.4 and in equation (3) respectively.

As the natural resource owners have the political power, their aim will be to obtain the highest level of their second period income. Thus, in order to finance human capital accumulation through public education, they will implement a tax policy which maximizes their income in period $t+1$. For a given natural resource stock level, in order to increase the rate of return to natural resource stock, $v_{t+1^{-}}$and equivalently the income earned from natural resources ownership, $m^{N} v_{t+1}$, in equation (31), and so maximize 
their second period income, natural resource owners will want to employ a higher number of "skilled" workers than the number that is sufficient to achieve the socially optimal aggregate output. Hence, natural resource owners will favor a high amount of human capital accumulation, and to finance this high level of human capital accumulation natural resource owners prefer a rather high tax rate, $\tau_{t}^{N}$.

Nevertheless, employing the number of skilled workers higher than the level required to produce the socially optimal aggregate output in the natural resources sector indicates a labor transfer from the manufacturing sector to the natural resources sector, reducing the marginal product of physical capital. On the whole, the excessively high tax rate preferred by the political authority of natural resource owners has a suppressing impact on the aggregate output in the economy. The lower aggregate output level obtained with this high tax rate is depicted at the point $\mathrm{D}$ in Figure 1. In order to maximize their second period income, when the natural resource owners have the political authority they prefer a tax rate, $\tau_{t}^{N}$, which is higher than the socially optimal tax rate, $\tau_{t}^{*}$, and which leads to a suboptimal aggregate output level. ${ }^{8}$ Hence, the tax rate, $\tau_{t}^{N}$, maximizing the second period income of natural resource owners also satisfies the following condition,

$\tau_{t}^{N}>\tau_{t}^{M}=\tau_{t}^{*}>\tau_{t}^{A}$

\footnotetext{
${ }^{8}$ The calibration explanations and results validating the statements in the Proposition 3 can be seen in Section 4.7. A related discussion is provided in Section A.4 in the Appendix.
} 


\section{Political Coalition of Manufacturers and Natural Resource Owners}

Manufacturers and natural resource owners can form a political coalition against a possible political authority of landowners. As explained in Section 4.3 and shown in Section 4.7, under the political authority of landowners, landowners want to keep almost the whole labor force in the agriculture sector, and so the tax rate they implement under their political authority is rather low. The very low tax rate and employing low numbers of skilled workers in the manufacturing and natural resources sectors are not preferred by manufacturers and natural resource owners since these will make both social groups economically worse off. As they set up a political coalition, their primary objective will be to maximize their joint income in period $t+1$. The coalition's joint income function is defined as an equal - weighted summation of each social group's second period income function, revealing the condition that the two groups share the political power equally in the coalition, as the following

$y_{t+1}^{M N}=y_{t+1}^{M \prime}+y_{t+1}^{N \prime}$

$y_{t+1}^{M N}=\left[w_{t+1}+\left(1-\tau_{t}^{M N}\right) b_{t}^{M} R_{t+1}\right]+\left[w_{t+1}+\left(1-\tau_{t}^{M N}\right) b_{t}^{N} R_{t+1}+m^{N} v_{t+1}\right]$

where $\tau_{t}^{M N}$ is the tax rate chosen by manufacturers-natural resource owners political authority. Since both manufacturers and natural resource owners get economic benefits from human capital accumulation and in order to maximize their joint second period income, so become economically better off than they would under a landowners political authority, they will implement the positive tax rate, $\tau_{t}^{M N}$, that is higher than the manufacturers' preferred tax rate, $\tau_{t}^{M}$, and lower than the natural resource owners' 
preferred tax rate, $\tau_{t}^{N}$, but maximizes their joint income. ${ }^{9}$ The simulation results in Section 4.7 imply that the tax rate, $\tau_{t}^{M N}$, satisfies the following condition

$\tau_{t}^{N}>\tau_{t}^{M N}>\tau_{t}^{M}=\tau_{t}^{*}>\tau_{t}^{A}$

Therefore, in order to maximize the second period joint income function, both manufacturers and natural resource owners will be content to a tax policy that is not originally preferred under either social group's political authority. Nonetheless, the tax rate, $\tau_{t}^{M N}$, does not achieve the efficient level of public education, and so the efficient human capital accumulation level from the society's point of view. Thus, this tax policy does not achieve the socially optimal aggregate output. The combination of the preferred tax rate, $\tau_{t}^{M N}$, and the aggregate output obtained with this tax policy is shown at the point $\mathrm{C}$ in Figure 1.

Political Coalition of Manufacturers and Landowners

Manufacturers and landowners may have an incentive to form a political coalition to protect themselves from the adverse economic effects of the political authority of natural resource owners and its distortionary tax policy. The natural resource owners support human capital accumulation mainly because they employ skilled workforce in the natural resources sector. However, under the political authority of natural resource owners an excessively high tax rate, $\tau_{t}^{N}$, is implemented to finance human capital accumulation through public education expenditures, and furthermore there occurs a substantial labor migration from the manufacturing sector to the natural resources sector, so this drastic

\footnotetext{
${ }^{9}$ The calibration explanations and results validating this statement can be seen in Section 4.7.
} 
decrease in employment level in the manufacturing sector suppresses the incomes of manufacturers making them economically worse off. Furthermore, $\tau_{t}^{N}$ is a much higher tax rate than the preferred tax rate by landowners, $\tau_{t}^{A}$, which is even lower than the socially optimal tax rate, $\tau_{t}^{*}$. When manufacturers and landowners form a political coalition, their main aim will be to obtain the highest amount of their joint income in period $t+1$. The coalition's joint income function can be defined as an equally weighted summation of each social group's second period income function since the two groups share the political power equally. Hence, we can define the coalition's joint income function in period $t+1$ as the following,

$y_{t+1}^{M A}=y_{t+1}^{M \prime}+y_{t+1}^{A \prime}$

$y_{t+1}^{M A}=\left[w_{t+1}+\left(1-\tau_{t}^{M A}\right) b_{t}^{M} R_{t+1}\right]+\left[w_{t+1}+s^{A} x_{t+1}\right]$

where $\tau_{t}^{M A}$ is the tax rate that maximizes the second period joint income of manufacturers and landowners. The sensitivity analysis results in Section 4.7 show that the tax rate, $\tau_{t}^{M A}$, is below the very high tax rate preferred by natural resource owners, and in the case of a political coalition of manufacturers and landowners, the preferred tax rate, $\tau_{t}^{M A}$, is equal to the tax rate chosen by manufacturers, $\tau_{t}^{M}$, and so also it is equal to the socially optimal tax rate, $\tau_{t}^{*}$, which achieves the maximum aggregate output level as demonstrated at point B in Figure 1. Hence, the simulation results imply the following ${ }^{10}$,

$\tau_{t}^{N}>\tau_{t}^{M N}>\tau_{t}^{M A}=\tau_{t}^{M}=\tau_{t}^{*}>\tau_{t}^{A}$

\footnotetext{
${ }^{10}$ The calibration explanations and results validating this statement can be seen in Section 4.7.
} 
Sensitivity Analysis

In all the simulations total population is equalized to 100 to get plausible numerical results, and for efficiency units of human capital the following function is used;

$h_{t+1}=h\left(e_{t}\right)=h\left(\tau_{t} b\right)=1+\left(\tau_{t} b\right)^{0.5}$

The initial parameter values used in the simulations are as the following:

$b=a Q_{t}=10 ; \alpha=0.3 ; \beta=0.6 ; \theta=0.4 ; \gamma=0.6 ; N_{t}=N_{t+1}=N=10$;

$Z_{t}=Z_{t+1}=Z=5 ; b_{t}^{M}=0.15 ; b_{t}^{N}=0.133 ; \sigma=30 ; \mu=20 ; \vartheta=40$

In all simulations the following two conditions are satisfied,

(1) $\frac{\partial Q_{t+1}^{M}}{\partial \delta_{t+1}^{M}}=\frac{\partial Q_{t+1}^{N}}{\partial \delta_{t+1}^{N}}=\frac{\partial Q_{t+1}^{A}}{\partial \delta_{t+1}^{A}}$, which refers to the condition of wage rate equalization across sectors in equation (22), $h_{t+1} w_{t+1}^{M}=h_{t+1} w_{t+1}^{N}=w_{t+1}^{A}=w_{t+1}$.

(2) $\delta_{t+1}^{M}+\delta_{t+1}^{N}+\delta_{t+1}^{A}=100$

Hence, using the above parameter values and taking into account the specified conditions, under different political coalitions the following calibration results are obtained: 
Table 1.Simulation Results under Different Political Coalitions

\begin{tabular}{|c|l|l|l|l|l|}
\hline $\begin{array}{c}\text { Political } \\
\text { Authority }\end{array}$ & \multicolumn{1}{|c|}{ Tax Rate } & \multicolumn{1}{|c|}{$\boldsymbol{\delta}_{\boldsymbol{t + 1}}^{M}$} & $\boldsymbol{\delta}_{\boldsymbol{t + 1}}^{N}$ & \multicolumn{1}{|c|}{$\boldsymbol{\delta}_{\boldsymbol{t + 1}}^{\boldsymbol{A}}$} & $\boldsymbol{Q}_{\boldsymbol{t + 1}}$ \\
\hline $\begin{array}{c}\text { Socially } \\
\text { Optimal }\end{array}$ & $\tau_{t}^{*}=0.362315$ & 51.0557 & 39.2914 & 9.6529 & 40.9107 \\
\hline Manufacturers & $\begin{array}{c}\tau_{t}^{M} \\
=0.362315\end{array}$ & 51.0557 & 39.2914 & 9.6529 & 40.9107 \\
\hline $\begin{array}{c}\text { Natural } \\
\text { Resource } \\
\text { Owners }\end{array}$ & $\tau_{t}^{N}=0.844238$ & 37.4938 & 52.0187 & 10.4875 & 32.8045 \\
\hline Landowners & $\tau_{t}^{A}=0.132704$ & 0.870404 & 0.952376 & 98.1772 & 20.5046 \\
\hline $\begin{array}{c}\text { Manufacturers- } \\
\text { Natural } \\
\text { Resource } \\
\text { Owners }\end{array}$ & $\begin{array}{c}\tau_{t}^{M N} \\
=0.573543\end{array}$ & 47.7302 & 42.7966 & 9.4732 & 39.5818 \\
\hline $\begin{array}{c}\text { Manufacturers- } \\
\text { Landowners }\end{array}$ & $\begin{array}{c}\tau_{t}^{M A} \\
=0.362315\end{array}$ & 51.0557 & 39.2914 & 9.6529 & 40.9107 \\
\hline
\end{tabular}

The following sensitivity analysis investigates how preferred tax rates and endogenously determined labor shares change when some of parameter values change under various coalitions.

Table 2.Sensitivity Analysis under Manufacturers' Political Authority

\begin{tabular}{|l|l|l|l|l|}
\hline$\alpha=0.5$ & $\tau_{t}^{M}=0.205907$ & $\delta_{t+1}^{M}=43.1165$ & $\delta_{t+1}^{N}=44.5706$ & $\delta_{t+1}^{A}=12.3129$ \\
\hline$\alpha=0.1$ & $\tau_{t}^{M}=0.684588$ & $\delta_{t+1}^{M}=60.721$ & $\delta_{t+1}^{N}=32.4023$ & $\delta_{t+1}^{A}=6.87632$ \\
\hline$\theta=0.6$ & $\tau_{t}^{M}=0.417286$ & $\delta_{t+1}^{M}=79.609$ & $\delta_{t+1}^{N}=16.4693$ & $\delta_{t+1}^{A}=3.92164$ \\
\hline$\theta=0.2$ & $\tau_{t}^{M}=0.296658$ & $\delta_{t+1}^{M}=22.6761$ & $\delta_{t+1}^{N}=61.5415$ & $\delta_{t+1}^{A}=15.7824$ \\
\hline$\beta=0.8$ & $\tau_{t}^{M}=0.330983$ & $\delta_{t+1}^{M}=67.6948$ & $\delta_{t+1}^{N}=14.2635$ & $\delta_{t+1}^{A}=18.0417$ \\
\hline$\beta=0.4$ & $\tau_{t}^{M}=0.390983$ & $\delta_{t+1}^{M}=25.5593$ & $\delta_{t+1}^{N}=71.2763$ & $\delta_{t+1}^{A}=3.16437$ \\
\hline$\gamma=0.8$ & $\tau_{t}^{M}=0.362315$ & $\delta_{t+1}^{M}=54.7539$ & $\delta_{t+1}^{N}=41.6492$ & $\delta_{t+1}^{A}=3.59691$ \\
\hline$\gamma=0.3$ & $\tau_{t}^{M}=0.362315$ & $\delta_{t+1}^{M}=28.9062$ & $\delta_{t+1}^{N}=24.458$ & $\delta_{t+1}^{A}=46.6357$ \\
\hline $\mathrm{N}=20$ & $\tau_{t}^{M}=0.362315$ & $\delta_{t+1}^{M}=42.8632$ & $\delta_{t+1}^{N}=50.8861$ & $\delta_{t+1}^{A}=6.25071$ \\
\hline $\mathrm{N}=5$ & $\tau_{t}^{M}=0.362315$ & $\delta_{t+1}^{M}=57.081$ & $\delta_{t+1}^{N}=28.7786$ & $\delta_{t+1}^{A}=14.1403$ \\
\hline $\mathrm{Z}=25$ & $\tau_{t}^{M}=0.362315$ & $\delta_{t+1}^{M}=35.4284$ & $\delta_{t+1}^{N}=28.977$ & $\delta_{t+1}^{A}=35.5946$ \\
\hline $\mathrm{Z}=3$ & $\tau_{t}^{M}=0.362315$ & $\delta_{t+1}^{M}=53.2834$ & $\delta_{t+1}^{N}=40.715$ & $\delta_{t+1}^{A}=6.00158$ \\
\hline
\end{tabular}

When $\alpha$ increases the marginal productivity of physical capital rises relative to the human capital and natural resource employed in the manufacturing sector. Therefore, the 
manufacturers prefer a lower tax rate compared to the tax rate when the value of $\alpha$ is lower, and also there will be a labor transfer from the manufacturing sector to the natural resource and agriculture sectors. When $\theta$ rises, marginal returns from human capital increase relative to physical capital and natural resource employed in the manufacturing sector. Hence, manufacturers now prefer a higher tax rate, and there will be a labor transfer from the natural resource and agriculture sectors to the manufacturing sector. When $\beta$ increases the marginal productivity of natural resource stock rises relative to human capital in the natural resource sector. The increase in the marginal productivity of natural resource stock has a small decreasing effect on the manufacturers' preferred tax rate, and it will bring about a labor migration from natural resource sector to the manufacturing and agriculture sectors. When $\gamma$ rises marginal returns from land increase relative to unskilled labor employed in the agriculture sector. The increase in marginal returns from land does not have any effect on the level of the tax rate chosen by manufacturers, though it creates a labor transfer from agriculture sector to manufacturing and natural resource sectors.

As the amount of natural resource stock increases, this effect does not change the manufacturers' preferred tax rate. Since now there is more natural resource stock to supply with human capital in the natural resource sector, and natural resource is an input used in manufacturing sector there will be a labor transfer from manufacturing and agriculture sectors to natural resource sector. As the amount of land increases, this does not change manufacturers' preferred tax rate. Since now there is more land to supply with raw labor and the labor migration is free across sectors, there will be a worker transfer from manufacturing and natural resource sectors to agriculture sector. 
Table 3. Sensitivity Analysis under Resource Owners' Political Authority

\begin{tabular}{|l|c|c|c|c|}
\hline$\alpha=0.5$ & $\tau_{t}^{N}=0.790478$ & $\delta_{t+1}^{M}=21.8404$ & $\delta_{t+1}^{N}=64.8675$ & $\delta_{t+1}^{A}=13.2922$ \\
\hline$\alpha=0.1$ & $\tau_{t}^{N}=0.963519$ & $\delta_{t+1}^{M}=54.6216$ & $\delta_{t+1}^{N}=37.9718$ & $\delta_{t+1}^{A}=7.406654$ \\
\hline$\theta=0.6$ & $\tau_{t}^{N}=0.737921$ & $\delta_{t+1}^{M}=74.2848$ & $\delta_{t+1}^{N}=21.2805$ & $\delta_{t+1}^{A}=4.4347$ \\
\hline$\theta=0.2$ & $\tau_{t}^{N}=0.907133$ & $\delta_{t+1}^{M}=12.5831$ & $\delta_{t+1}^{N}=72.967$ & $\delta_{t+1}^{A}=14.4499$ \\
\hline$\beta=0.8$ & $\tau_{t}^{N}=0.62967$ & $\delta_{t+1}^{M}=64.7119$ & $\delta_{t+1}^{N}=15.901$ & $\delta_{t+1}^{A}=19.3871$ \\
\hline$\beta=0.4$ & $\tau_{t}^{N}=0.971226$ & $\delta_{t+1}^{M}=6.91574$ & $\delta_{t+1}^{N}=90.4025$ & $\delta_{t+1}^{A}=2.68173$ \\
\hline$\gamma=0.8$ & $\tau_{t}^{N}=0.838916$ & $\delta_{t+1}^{M}=40.943$ & $\delta_{t+1}^{N}=55.2206$ & $\delta_{t+1}^{A}=3.83642$ \\
\hline$\gamma=0.3$ & $\tau_{t}^{N}=0.889706$ & $\delta_{t+1}^{M}=17.4031$ & $\delta_{t+1}^{N}=31.5812$ & $\delta_{t+1}^{A}=51.0157$ \\
\hline $\mathrm{N}=20$ & $\tau_{t}^{N}=0.904211$ & $\delta_{t+1}^{M}=25.1397$ & $\delta_{t+1}^{N}=68.1107$ & $\delta_{t+1}^{A}=6.74956$ \\
\hline $\mathrm{N}=5$ & $\tau_{t}^{N}=0.781715$ & $\delta_{t+1}^{M}=47.7192$ & $\delta_{t+1}^{N}=37.0536$ & $\delta_{t+1}^{A}=15.2272$ \\
\hline $\mathrm{Z}=25$ & $\tau_{t}^{N}=0.872229$ & $\delta_{t+1}^{M}=23.5285$ & $\delta_{t+1}^{N}=38.2374$ & $\delta_{t+1}^{A}=38.2341$ \\
\hline $\mathrm{Z}=3$ & $\tau_{t}^{N}=0.84102$ & $\delta_{t+1}^{M}=39.5423$ & $\delta_{t+1}^{N}=53.928$ & $\delta_{t+1}^{A}=6.52965$ \\
\hline
\end{tabular}

When $\alpha$ increases the marginal productivity of physical capital rises relative to the human capital and natural resource employed in the manufacturing sector. Since the natural resource owners own physical capital they now prefer a lower tax rate, and there occurs a labor transfer from the manufacturing sector to the natural resource and agriculture sectors. When $\theta$ rises, marginal returns from human capital increase relative to physical capital and natural resource employed in the manufacturing sector. Thus, natural resource owners now prefer a lower tax rate. Yet, because of the unconstrained labor migration across sectors, there will be a labor transfer from the natural resource and agriculture sectors to the manufacturing sector. When $\beta$ increases the marginal productivity of natural resource stock rises relative to human capital in the natural resource sector. The increase in the marginal productivity of natural resource reduces the tax rate preferred by the natural resource owners, and it will bring about a labor migration from natural resource sector to the manufacturing and agriculture sectors. As $\gamma$ rises marginal returns from land increase relative to unskilled labor employed in the agriculture sector. The 
increase in marginal returns from land has a small reducing effect on the natural resource owners' preferred tax rate, though it creates a labor transfer from agriculture sector to manufacturing and natural resource sectors.

When the amount of natural resource stock increases since now there is more natural resource stock to supply with human capital in the natural resource sector, natural resource owners prefer a higher tax rate, and there occurs a labor migration from manufacturing and agriculture sectors to the natural resource sector. As the amount of land in production increases since there is more land to supply with unskilled workers, and the wage rates across sectors are equalized through free labor migration, there will be an employment transfer from the manufacturing and natural resource sectors to the agriculture sector.

Table 4. Sensitivity Analysis under Manufacturers-Resource Owners Coalition

\begin{tabular}{|l|l|l|l|l|}
\hline \multicolumn{1}{|c|}{$\alpha=0.5$} & $\tau_{t}^{M N}=0.408029$ & $\delta_{t+1}^{M}=38.4396$ & $\delta_{t+1}^{N}=49.673$ & $\delta_{t+1}^{A}=11.8874$ \\
\hline$\alpha=0.1$ & $\tau_{t}^{M N}=0.834666$ & $\delta_{t+1}^{M}=59.2746$ & $\delta_{t+1}^{N}=33.8762$ & $\delta_{t+1}^{A}=6.84913$ \\
\hline$\theta=0.6$ & $\tau_{t}^{M N}=0.537046$ & $\delta_{t+1}^{M}=78.4471$ & $\delta_{t+1}^{N}=17.5973$ & $\delta_{t+1}^{A}=3.95563$ \\
\hline$\theta=0.2$ & $\tau_{t}^{M N}=0.614792$ & $\delta_{t+1}^{M}=19.4477$ & $\delta_{t+1}^{N}=66.1485$ & $\delta_{t+1}^{A}=14.4038$ \\
\hline$\beta=0.8$ & $\tau_{t}^{M N}=0.443004$ & $\delta_{t+1}^{M}=67.1516$ & $\delta_{t+1}^{N}=14.6854$ & $\delta_{t+1}^{A}=18.1631$ \\
\hline$\beta=0.4$ & $\tau_{t}^{M N}=0.674599$ & $\delta_{t+1}^{M}=20.0516$ & $\delta_{t+1}^{N}=77.1866$ & $\delta_{t+1}^{A}=2.76186$ \\
\hline$\gamma=0.8$ & $\tau_{t}^{M N}=0.574198$ & $\delta_{t+1}^{M}=51.117$ & $\delta_{t+1}^{N}=45.3386$ & $\delta_{t+1}^{A}=3.54433$ \\
\hline$\gamma=0.3$ & $\tau_{t}^{M N}=0.566046$ & $\delta_{t+1}^{M}=27.4378$ & $\delta_{t+1}^{N}=26.8053$ & $\delta_{t+1}^{A}=45.757$ \\
\hline $\mathrm{N}=20$ & $\tau_{t}^{M N}=0.616633$ & $\delta_{t+1}^{M}=38.3406$ & $\delta_{t+1}^{N}=55.6092$ & $\delta_{t+1}^{A}=6.05017$ \\
\hline $\mathrm{N}=5$ & $\tau_{t}^{M N}=0.535891$ & $\delta_{t+1}^{M}=54.8998$ & $\delta_{t+1}^{N}=31.1079$ & $\delta_{t+1}^{A}=13.9923$ \\
\hline $\mathrm{Z}=25$ & $\tau_{t}^{M N}=0.569072$ & $\delta_{t+1}^{M}=33.3379$ & $\delta_{t+1}^{N}=31.6113$ & $\delta_{t+1}^{A}=35.0508$ \\
\hline $\mathrm{Z}=3$ & $\tau_{t}^{M N}=0.573953$ & $\delta_{t+1}^{M}=49.7765$ & $\delta_{t+1}^{N}=44.3361$ & $\delta_{t+1}^{A}=5.88739$ \\
\hline
\end{tabular}

Under the political coalition of manufacturers and natural resource owners, the directions of labor transfer are the same as in the manufacturers' political authority and natural 
resource owners' political authority. From the point of view of manufacturers, when $\theta$ rises since now manufacturers own natural resource stock and obtain income returns from natural resources ownership, as in the case of political authority of natural resource owners, the coalition members prefer a lower tax rate.

The sensitivity analysis results for the cases of the aggregate output and the manufacturers - landowners coalition are the same as the results of political authority of manufacturers. These simulation conclusions are consistent with the theoretical model.

Under the political authority of landowners, the same parameter changes which have been observed in other coalitions do not have any effect on the landowners' preferred tax rate and on the endogenous allocation of labor shares. Only the second period income of landowners increases when $\gamma$ or the amount of land, $Z$, rise.

\section{CONCLUSION}

Chapter one proposes a theoretical model about the relationship between natural resource abundance and human capital accumulation from a political economy perspective, unlike most of the existing studies which mainly focus on either economic effects of natural resource abundance on economic growth, or rent-seeking activities. The analysis suggests that the ultimate impact of the natural resource abundance on economic growth and on the accumulation of human capital depends on which social group(s) holds the political power in the society and on their preferred tax policy to finance human capital accumulation through public education expenditures. 
First the socially optimal tax rate that achieves the efficient human capital accumulation level and maximum aggregate output is found. Then, public education policies under different political economy formations are investigated. Under each political coalition, the second period aggregate output and labor shares in the three sectors are endogenously changing with the unique tax policy each political coalition imposes. When the landowners hold the political authority, mainly as a consequence of a substantial reduction in the return from land which is caused by the increase in human capital, landowners favor human capital accumulation at a rather low degree. When the manufacturers have political power under either their own political authority or in a coalition with the landowners, since human capital is complementary to both physical capital and natural resources stock, and also the natural resource output is used as a factor of production in the manufacturing sector, the tax policies of these two political formations become the same with the socially optimal tax policy.

On the other hand, when the natural resource owners hold the ultimate political power, they want to get the full advantage of the complementarity between human capital and natural resources stock, having a rent - seeking point of view. In order to extract the highest possible return from the natural resources stock, they prefer an excessively high tax rate which causes the aggregate output, and so economic growth to be at suboptimal levels. Although the political coalition of manufacturers and natural resource owners implement a lower tax rate, it does not still completely remedy the distortionary tax effect hurting aggregate output and economic growth. Hence, even though natural resource owners favor human capital, their preferred tax rates diminish aggregate output which leads to the less funds available for human capital accumulation in the future generations. 
The political economy analysis proposed in this paper implies a multi - social class economic conflict among the natural resource owners, manufacturers and landowners, and provides an answer for the highly differentiated economic performances of the natural resource abundant countries.

\section{REFERENCES}

Acemoglu, D. (2009). Introduction to Modern Economic Growth. Princeton.

Acemoglu, D. and Robinson, J. A. (2000). Political Losers as a Barrier to Economic Development. American Economic Review, Papers and Proceedings, 90 (2): 126-130.

Acemoglu, D. and Robinson, J. A. (2006). Economic Origins of Dictatorship and Democracy. Cambridge University Press.

Acemoglu, D. and Robinson, J. A. (2006). Economic Backwardness in Political Perspective. American Political Science Review, 100 (1):115-131.

Acemoglu, D., Johnson, S. and Robinson, J.A. (2001). The colonial origins of comparative development: An empirical investigation. American Economic Review 91: 1369-1401.

Acemoglu, D., Johnson, S. and Robinson, J.A. (2002). Reversal of Fortune: Geography and Institutions in the Making of the Modern World Income Distribution. Quarterly Journal of Economics, 117: 1231-1294.

Aten, B., Heston, A. and Summers, R. (2009). Penn World Table Version 6.3. Center for International Comparisons of Production, Income and Prices at the University of Pennsylvania.

Birdsall, N., Pinckney, T. and Sabot, R. (2001). Natural Resources, Human Capital, and Growth in Resource Abundance and Economic Growth, R. M. Auty ed. Oxford University Press.

Bourguignon, F. and Verdier, T. (2000). Oligarchy, democracy, inequality and growth. Journal of Development Economics, 62: 285-313. 
Bravo-Ortega, C. and De Gregorio, J. (2005). The relative richness of the poor? Natural resources, human capital, and economic growth. Policy Research Working Paper No. 3484, the World Bank, Washington D.C.

Easterly, W. and Levine, R. (2003). Tropics, Germs, and Crops: the Role of Endowments in Economic Development. Journal of Monetary Economics, 50: 3-39.

Engerman, S. and Sokoloff, K. L. (2000). Factor Endowment, Inequality, and Paths of Development among New World Economies. Mimeo, UCLA.

Galor, O. and Moav, O. (2004). From Physical to Human Capital: Inequality in the Process of Development. Review of Economic Studies, 71: 1001-1026.

Galor, O., Moav, O., and Vollrath, D. (2009). Inequality in Land Ownership, the Emergence of Human Capital Promoting Institutions, and the Great Divergence. Review of Economic Studies, 76: 143-179.

Gerlagh, R. and Papyrakis, E. (2004). The resource curse hypothesis and its transmission channels. Journal of Comparative Economics, 32: 181-193.

Glaeser, E.L., La Porta, R. Lopez-De-Silanes, F. and Shleifer, A. (2004). Do Institutions Cause Growth? Journal of Economic Growth, 9: 271-303.

Gylfason, T. (2001). Natural resources, education, and economic development. European Economic Review, 45: 847-859.

Hall, R. E. and Jones, C. I. (1999). Why Do Some Countries Produce So Much More Output Per Worker Than Others? The Quarterly Journal of Economics, 114: 83-116.

Karayalcin, C. and Ulubasoglu, M. A. (2010). Romes without Empires: Primate Cities, Political Competition, and Economic Growth. Working Paper, Florida International University.

Lagerlof, N. P. and Tangeras, T. (2008). From rent seeking to human capital: a model where resource shocks cause transitions from stagnation to growth. Canadian Journal of Economics, 41(3): 760-780.

Matsuyama, K., (1992). Agricultural productivity, comparative advantage, and economic growth. Journal of Economic Theory, 58: 317-334.

Mehlum, H., Moene, K., and Torvik, R. (2006). Institutions and the resource curse. Economic Journal, 116: 1-20.

North, D.C., (1981). Structure and Change in Economic History. W.W. Norton\&Co., New York. 
Persson, T. and Tabellini, G. (2000). Political Economics: Explaining Economic Policy. MIT Press.

Robinson, J.A. and Torvik, R. (2005). White elephants. Journal of Public Economics, 89: 197-210.

Robinson, J.A., Torvik, R., and Verdier, T. (2006). Political foundations of the resource curse. Journal of Development Economics, 79: 447-468.

Rodrik, D., Subramanian, A., and Trebbi, F. (2004). Institutions Rule: The Primacy of Institutions over Geography and Integration in Economic Development. Journal of Economic Growth, 9: 131-165.

Sachs, J. and Warner, A.M. (1995). Natural Resource Abundance and Economic Growth. NBER Working Paper 5398.

Stijns, J.P., (2006). Natural Resource Abundance and Human Capital Accumulation. World Development, 34 (6): 1060-1083.

Torvik, R., (2009). Why do some resource abundant countries succeed while others do not? Mimeo, Norwegian University of Science and Technology.

van der Ploeg, F., (2009). Challenges and Opportunities for Resource Rich Economies. Mimeo, OXCARRE, Oxford University. 


\section{CHAPTER II}

\section{INTRODUCTION}

The Industrial Revolution marked the start of a long series of social and economic transformations leading to substantial divergence across countries in terms of income per capita, economic development, and political and economic institutions. The period of industrialization both intensified social class stratification by creating new classes and increased the demand for human capital, a complementary factor of production to physical capital. Because of credit market imperfections, public education spending has become the primary tool for human capital accumulation to maintain sustainable economic growth (Galor et al., 2009, and Lagerlof and Tangeras, 2008). Nonetheless, human capital may not be as beneficial for some sectors in the economy, and the social classes who operate in these sectors as the owners of primary factors of production would not support human capital accumulation through public education. For instance, Galor et al. (2009) argue that given the low level of complementarity between human capital and land, increases in human capital reduce the return to land as labor migrates from the agricultural sector to the manufacturing sector. When they have political power the landowners would choose to invest little, if at all, in public education unless they also earn returns from the industrial sector.

The main purpose of Chapter two is to examine the association between public education spending, and the economic power and political influence of various social classes. Furthermore, as political influence is mediated through political institutions, we explore 
how different governance indicators affect the overall impact of the political influence of social classes on public education spending.

The choice of sectors of production and social class stratification are derived from the multi-sector, multi-class models in Acemoglu and Robinson (2006), and Galor et al. (2009). Here we model three sectors: the natural resources, manufacturing, and agricultural sectors. Hence, the social classes whose economic power and political influence on public education spending are investigated are the natural resource owners, manufacturers and landowners.

Certain aspects of the link between economic sectors and growth have been analyzed in detail in the literature. Matsuyama (1992) examined the relationship between agricultural productivity and economic growth in a two-sector model, and argued that agricultural productivity has a positive effect on economic growth in a closed economy, but in the case of a small, open economy there is a negative relationship between agricultural productivity and economic growth. In his model, he does not differentiate between an agriculture sector and a natural resource sector. Lagerlof and Tangeras (2008) analyze the trade-off between rent seeking activities such as resource competition or land conquest and productive activities such as trade or manufacturing which use human capital as a factor of production, and show that an increase in the availability of natural resources increases rent seeking activities and reduces human capital productivity, and is harmful for economic growth in the key takeoff period. Bourguignon and Verdier (2000) explore in a political economy model the conditions under which the educated oligarchy chooses 
to invest in the education of the poor and so initiate a transition to democracy by integrating the educated poor into the political participation process.

Empirical studies on the determinants of public education spending, such as Busemeyer (2007), examine the determinants of public education spending in 21 member countries of the Organization for Economic Co-operation and Development (OECD) in a pooled time-series analysis. The control variables used include the degree of tax revenue decentralization, veto index, and cabinet shares of social democrats, Christian democrats, and conservatives. In a study of the determinants of public education spending in the United States, Poterba (1997) highlights the importance of the effect of demographic composition on the level of per-child education spending.

The main results we obtain in what follows are that the political influence of natural resource owners and landowners has a direct negative effect on public education spending, whereas the political power of manufacturers exerts a positive one. Moreover, the quality of different dimensions of governance and institutions plays a significant role in determining the overall net effect of the political influence of different social classes on public education spending. The rest of the paper is organized as follows. Section 2 describes the data set and the econometric strategy. Section 3 discusses estimation results, and section 4 presents concluding remarks.

\section{ECONOMETRIC STRATEGY AND DATA DETAILS}

The main hypothesis proposed in this paper follows from the multi-social class theoretical model of Acemoglu and Robinson (2006). Social groups are classified 
according to the type of activity from which they generate their income and their ownership of factors of production in different sectors. As a result, economic interests and preferences of different social groups diverge. As one social class's economic contribution to aggregate output increases, that class gains in political power relative to other groups, and social and economic policy decisions increasingly reflect that group's economic interests. Therefore relative economic contribution to the aggregate output maps into relative political influence in the society.

One important question for empirical work is the choice of a metric to measure the political power of a given social class. The majority of the papers in the literature that try to proxy the political power of social classes use the political party left-right spectrum variables from the Database of Political Institutions (DPI 2009) (Beck et al., 2009). However, as the DPI 2009 codebook authors state, the data sources reveal very little information on party platforms, social groups supporting these parties, and agendas regarding economic policy. In what follows, I use instead a number of macroeconomic indicators to proxy the influence social classes may bring to bear in the political arena. Specifically, total natural resource rents, manufacture exports and agriculture value added (as shares of GDP) are adopted as proxy variables to measure the political influence of the natural resource owners, manufacturers, and landowners, respectively. The motivation behind this choice is to use the mapping from income to political power.

Further, as political institutions mediate between political power and political outcomes, to show the mediating effect of political institutions I use interaction variables of different governance indicators with proxies of political power in the empirical 
estimation. A similar method is followed in the literature on natural resources and economic growth. For instance, Mehlum et al. (2006), Boschini et al. (2007) and Brunnschweiler (2008) use in their empirical models the interactions between various natural resource measures and institutional quality indicators to estimate the total effect of natural resource abundance on economic development. The total natural resource rents (as a percentage of the GDP), which is assumed to be the proxy variable to measure political influence of owners of natural resources, is calculated as a composite variable of oil rents, natural gas rents, coal rents, forest rents, and mineral rents. For all five components, rents are the difference between the value of production of the natural resource at world prices and the total cost of its production. The minerals included in the calculation of mineral rents are tin, gold, lead, zinc, iron, copper, nickel, silver, bauxite and phosphate. Another possible proxy variable that may be used for the political influence of natural resource owners is the fuel-ore-metals exports, calculated as a summation of fuel, ores and metals exports. Although the estimation results of these two composite proxy variables are similar, total natural resource rents (resource rent in the estimations) is a better proxy variable than fuel-ore-metals exports especially in terms of identifying the three sectors; natural resource, manufacturing and agriculture separately from each other, for the coverage of fuel-ore-metals exports includes some manufactured natural resource products used in metallurgy and cermet industries.

Manufacture exports are used to proxy the political influence that the manufacturers possess. Another possible macroeconomic indicator for this purpose is manufacturing value added. Manufacture exports broadly cover chemicals, machinery and transport equipment, and miscellaneous manufactured goods, while manufacturing 
value added includes manufactures of agricultural products. Hence, manufacture exports provide a better representation of the manufacturing sector than manufacturing value added. Agriculture value added, the assumed proxy variable to measure the political influence that the landowners possess, includes the value added amounts of hunting, fishing, cultivation of crops, and livestock production. Another possible indicator that could have potentially been used as a proxy would have been agricultural raw materials exports, but this variable only includes crude materials, so its coverage is not as good as the coverage of agriculture value added in terms of representing the agriculture sector production in an accurate way.

There are three governance quality indicators, political stability and absence of violence (polstab in the estimation tables), regulatory quality (regquality in the estimation tables), and rule of law (ruleoflaw in the estimation tables), used in regressions as control variables by themselves and as a component of interaction terms with the proxy variables. Political stability and absence of violence measures the probability that the government will be destabilized or overthrown by unconstitutional or violent means. Regulatory quality captures perceptions of the ability of the government to formulate and implement policies and regulations which favor private sector development. Rule of law covers issues such as the nature of contract enforcement, property rights, the police, and the courts, and also the likelihood of crime and violence (Kaufmann et al., 2010). In the regressions, the political influence of the social classes is allowed to affect public education spending both directly and through the channel of governance indicators. In the literature, the rule of law is often used to capture institutional quality (Brunnschweiler, 2008 and Bulte et al., 2005). The main purpose there is to explore the effect of natural 
resource abundance on development and economic growth in countries with differing institutional quality levels. The three governance indicators identify different dimensions of the governance rules and institutions through which the authority and policies are exercised in a country. Therefore, the political influence of each of the three social classes may interact with each of the governance indicators, and so affects public education spending in a different way. Thus, for the purposes of this paper it is useful to employ different governance indicators in the regressions.

Table 1 presents the descriptive statistics. The primary data sources are the World Development Indicators (WDI), Global Development Finance (GDF), and Worldwide Governance Indicators (WGI) from the World Bank. Public education spending (as a share of GDP) is the dependent variable for the subsequent estimations throughout the paper. The proxy variables, total natural resources rents, manufacture exports, and agriculture value added, indicate the economic contribution of the natural resource owners, manufacturers and landowners, and are assumed to represent the political influence the natural resource owners, manufacturers and landowners possess respectively within a country. Therefore the main assumption here is that as a social group's economic contribution to the aggregate output increases, its political influence in the society also increases.

The data for the governance indicators are collected from the Worldwide Governance Indicators. The numerical values of the indicators change between -3.5 and +3.5 during the period 1996-2009. If the value of an indicator increases this refers to an improvement in that governance quality category. The log value of GDP per capita 
(lngdpcapita in the estimation tables), school-age population share in total population, old population (age 65 and over) share in total population (Busemeyer, 2007, Fernandez and Rogerson, 1997, and Poterba, 1997), GDP per capita growth rate (gdpgrowth in the estimation tables) (Busemeyer, 2007), and openness degree are other explanatory variables that are found to be correlated with public education spending in the related literature. School-age population share is the population of the age-group theoretically corresponding to a given level of education as indicated by theoretical entrance age and duration divided by total population.

\section{ESTIMATION RESULTS}

Our aim here is to estimate the effect of the political influence of different social classes on public education spending working through the political institutions. To eliminate the possible omitted variable bias country and year-fixed effects are controlled in a panel data estimation covering the period 1996-2009 for 132 countries. For all regressions, the results of an $\mathrm{F}$ test indicate that there are significant country level effects, so the fixed effects panel data estimation is a more appropriate model specification than the pooled OLS. The benchmark estimation is written in equation (1) as the following,

$$
\text { public education spending }_{i t}=\beta_{0}+\beta_{1} \text { resource rent }_{i t}+\beta_{2} \text { manufacture }_{i t}+
$$

$\beta_{3}$ agriculture $_{i t}+\beta_{4}(\text { resource rent } * \text { governance indicator })_{i t}+$

$\beta_{5}(\text { manufacture } * \text { governance indicator })_{i t}+$

$\beta_{6}(\text { agriculture } * \text { governance indicator })_{i t}+\beta_{7}$ governance indicator ${ }_{i t}+\beta_{8}^{\prime} Z_{i t}^{\prime}+$ $\sigma_{i}+\mu_{t}+\varepsilon_{i t}$ 
where public education spending is the dependent variable, $\sigma$ represents country fixed effects, $\mu$ captures time fixed effects, and $\varepsilon_{i t}$ is the error term. The proxy variables, total natural resources rents (resource rent), manufacture exports (manufacture), and agriculture value-added (agriculture), are used to measure the political influence of the natural resource owners, manufacturers, and landowners, respectively. Governance indicator refers to one of the three institutional quality indicators discussed in the previous section. The interaction terms of the proxy variables and the governance indicator demonstrate how the proxy variables interact with each of the three governance indicators.

In the equation (1), $Z$ is a vector of explanatory variables which includes the log value of GDP per capita, school-age population share in total population, old population share in total population, GDP per capita growth rate, and openness degree. The use of these variables is standard in the literature on the political economy of institutions and public education spending.

All the estimations in Table 2 and Table 3 report the point estimates and standard errors in parentheses. The advantage of reporting point estimates is that they show the effects of marginal changes in the explanatory variables on public education spending. In all regressions the coefficients of log GDP per capita and GDP growth rate are negative and significant. This finding may be the result of the case that when countries become richer private education options may be more widespread and preferred compared to public education. Table 2 reports the estimation results for the comprehensive sample. Column (1) shows the result of the estimation without any interaction term. 
In all estimations in Table 2 resource rent shows a direct negative and statistically significant effect on public education spending. Controlling for the political influence of the manufacturers and landowners through manufacture export and agriculture value added, respectively, the total impact of resource rent on public education spending is measured by its direct effect as well as through its indirect effects through political institutions proxied here by governance indicators. The interactions of resource rents with political stability and absence of violence (resourcepolstab in Column (2)), with regulatory quality (resourceregquality in Column (3)), and with rule of law (resourcerule in Column (4)) are statistically significant. The total effect of a marginal increase in resource rent implied by equation (1) is

$$
\frac{\partial \text { pubedu }}{\partial \text { resourcerent }}=\hat{\beta}_{1}+\hat{\beta}_{4} \text { governance indicator }
$$

Hence when interacted with the variable "political stability and absence of violence" the effect of the political power of the natural resource owners on public education spending can be computed as

$-0.0384+(-0.0102 * 0.0342752) \cong-0.039$

where 0.0342752 is the sample mean of political stability and absence of violence. In Column (4), through the channel of rule of law the total impact of resource rent on public education spending can be computed as,

$-0.0411+(-0.02 * 0.0872166) \cong-0.043$

where 0.0872166 is the sample mean of rule of law. 
Political stability and absence of violence measures the possibility that a government is destabilized or even completely changed by unconstitutional and illegal terrorist activities. Rule of law identifies the characteristics of contract enforcement, property rights, actions of the police and courts. On the basis of the numerical results obtained above, on average resource rent exerts a negative effect on public education spending. As the levels of political stability and absence of violence, and rule of law improve this negative effect intensifies. Since resource rent is used as a proxy for the political influence of the natural resource owners, when total resource rent, and thus, the political influence of natural resource owners increases within a country with high degrees of political stability and absence of violence as well as the rule of law, such as in northern European countries, politically powerful natural resource owners may prefer to engage in rent-seeking activities instead of investing in public education for human capital accumulation, design contract enforcement and actions of the police and courts according to their interests because there are no high level unconstitutional, terrorist activities which can reduce the political power of natural resource owners substantially. On the other hand, within a country where political stability is weak and there is a high risk of violent activities, when natural resource owners' political influence increases, if they face a certain threat from opposing groups especially with a demand for a more educated labor force, natural resource owners, facing the possibility of losing their political power, may invest more in public education.

Manufacture export, proxy variable for the political influence of the manufacturers, exerts a direct positive and significant effect (except Column (2)) on public education spending. Since skilled workers are needed in the industrial sectors, 
when the manufacturers have more political influence they prefer to invest more in human capital accumulation. Although the coefficients of interaction terms of manufacture export and governance indicators are positive they appear insignificant.

The political influence of landowners, proxied by agriculture value added, exerts a direct negative and statistically significant at the 5 percent level effect on public education spending. This result of the landowners' negative political influence on public education spending is consistent with the argument that since agricultural production does not require any skilled labor and educated workers migrate from agriculture sector to industrial sectors, when the landowners become politically more powerful this negatively affects public education spending levels within countries. The coefficients of the interaction terms of agriculture value added with regulatory quality (agriregquality) and rule of law (agrirule) appear statistically significant at 5 percent level and positive. The finding of significant and positive coefficients of the interaction terms suggests that the negative effect of the political influence of landowners on public education spending diminishes as the levels of regulatory quality and rule of law improve within a country. Nevertheless, the magnitudes of the interaction terms are not big enough to completely eliminate the negative direct effect of landowners' political influence on public education spending, even for countries having higher levels of the above mentioned governance indicators.

In order to determine the strength of the proxy variables estimated in previous regressions the baseline fixed effects regression is performed again with a sub-sample consisting of 69 middle-income countries defined as the countries which have gross 
national income (GNI) per capita between $\$ 1,026$ and $\$ 12,475$ by the World Bank. The results are reported in Table 3. The coefficients of the log value of GDP per capita and old population share are statistically significant at the 5 percent level. The negative coefficient of GDP per capita indicates that as countries get richer; this negatively affects public education spending because private education options may be more preferred. The positive coefficient of old population share suggests that within middle income countries as the population gets older, in order to replace the lost workforce public education spending will increase.

In all estimations, the proxy variables, resource rent, manufacture export, and agriculture value added preserve their previously found effects on public education spending at the statistically significant 5 percent level. Natural resource owners' political influence exerts a negative effect on public education spending. However, the coefficients of interaction terms of resource rent and governance indicators are no longer statistically significant. Political stability and absence of violence, and rule of law appear to be important channels to determine the total effect of manufacture export on public education spending. As the levels of political stability and absence of violence, and rule of law improve the positive effect of manufacturers' political influence on public education spending becomes stronger. Compared to the estimation results obtained using the comprehensive sample, now with the sample of middle income countries the magnitude of the positive effect of a marginal increase in manufacture export on public education spending is greater. Consistent with the previously found results, the improvements in regulatory quality and rule of law diminish the negative effect of landowners' political influence on public education spending. 
Furthermore two governance indicators and their interactions with resource rent, manufacture export, and agriculture value added are simultaneously included into the unbalanced panel data regressions (the comprehensive sample is used for the estimations) in order to investigate the validity of initial results. Resource rent and agriculture value added retain their direct negative and statistically significant effect on public education spending. There is a slight loss of significance in the manufacture export's positive impact on public education spending. Regarding the effects of governance indicators working through the interaction terms, an increase in the degree of rule of law intensifies the negative effect of natural resource owners' political influence on public education spending. Improvements in political stability and absence of violence, as in estimation results with middle income countries sample, reinforces the positive impact of manufacturers' political power. An increase in the level of regulatory quality diminishes the negative effect of landowners' political influence.

\section{CONCLUDING REMARKS}

This paper presents empirical results about the effect of economic power and political influence of different social classes on public education spending in panel data estimation. Macroeconomic indicators are used as proxy variables to define the political influence of the social classes. The governance indicators, political stability and absence of violence, regulatory quality, and rule of law, are used to explore how the political influence of social classes interacts with the different aspects of institutions, and how 
these interactions affect the overall relationship between the social groups' political influence and public education spending.

Resource rent is assumed as the proxy variable to represent the political influence of the natural resource owners. It shows a direct negative effect on public education spending. The interaction terms of resource rent with political stability-absence of violence and rule of law also contribute significantly to the overall impact of the political influence of natural resource owners. At low levels of political stability-absence of violence and rule of law, when the political power of natural resource owners increases, in the presence of strong opposition and unconstitutional activities, being afraid of losing their political influence and being overthrown, natural resource owners invest more in public education. On the other hand, at high levels of political stability- absence of violence and rule of law when the political influence of natural resource owners increases through rising resource rents, since they do not face a significant degree of strong opposition and terrorist activities, natural resource owners may engage into rent-seeking and kleptocracy activities, and invest less in public education.

In most regressions manufacture export, the proxy variable assumed to define the political influence of the manufacturers, exerts a direct positive and statistically significant effect on public education spending. Therefore as the political influence of manufacturers increases this positively affects public education spending level. Considering estimations done with the middle income countries sample, the statistically significant and positive coefficients of the interaction terms of manufacture export with political stability-absence of violence and rule of law indicate that improvements in these 
governance indicators reinforce the positive influence the manufacturers possess within a country.

Agriculture value added is assumed to be the proxy for the economic power and political influence of the landowners. It shows a direct negative effect on public education spending indicating that when the political influence of landowners increases this negatively affects the level of public education spending. Through the interaction terms, increases in the levels of regulatory quality and rule of law diminish this direct negative effect.

In the cases of controlling multiple interaction terms simultaneously and repeating the benchmark regressions with a different sample resource rent, manufacture export, and agriculture value added preserve the nature and significance of their effects on public education spending in most of the estimations. Using resource rents, manufacture exports, and agriculture value added as proxy variables to define the political influences of the social classes may be a strong assumption, but there is no study in political science literature presenting good data which identify political party platforms according to the social classes supporting these parties and economic policy agendas.

Regarding how this paper is related to the resource abundance, institutional quality and economic growth literature, Mehlum et al. (2006) argue that resource abundance is beneficial for economic growth when the institutions are producer friendly and harmful for economic growth when the institutions are grabber friendly. They use the share of primary exports in GNP in 1970 from Sachs and Warner (1995) as resource abundance indicator and a composite index for institutional quality. Boschini et al. (2007) 
draw attention to the interactions between institutional quality and different types of resources, and their varying effects on economic growth. Brunnschweiler (2008) uses subsoil wealth per capita as resource abundance indicator, and rule of law and government effectiveness from the Worldwide Governance Indicators to define institutional quality. She finds that resource abundance has a direct positive effect on economic growth although the negative coefficients of the interaction terms suggest that this positive effect diminishes as the quality of institutions improves. In all these studies, the dependent variable is an economic growth indicator. Aslaksen (2007) uses panel data specification controlling for country and time fixed effects to estimate the impact of resource abundance on corruption.

The present paper provides a contribution to the natural resources and economic growth literature in the sense that when the economic power and political influence of the natural resource owners, proxied by the resource rents, increase this negatively affects public education spending levels. Resource rent is a composite variable including oil rents, natural gas rents, forest rents, coal rents, and minerals rents. Hence, these five types of natural resource rents altogether are assumed to define the economic market power and relative political influence of natural resource owners.

In order to explore different aspects of the interaction between institutional quality and political influences of the social classes, three governance indicators are used in the regressions. The estimation results examining the effects of proxy variables show that through the interaction terms the governance indicators play significant roles in determining the total impacts of natural resource owners', manufacturers', and 
landowners' political influence on public education spending, referring to the argument that the quality of political institutions is an important factor in determining economic development which is discussed in detail in economic growth and political economy literature.

Future research prospects include single country case studies to find out how countryspecific political party platforms and social class structure affect economic development; country-group studies to explore how similar geographical, regional or economic conditions, potential political conflicts between countries affect economic growth. Also, the integration of political coalition structure into the empirical framework would be useful. 
Table 5. Descriptive Statistics

\begin{tabular}{|c|c|c|c|c|c|c|}
\hline Variable & & Mean & Std. Dev. & Min & Max & Observations \\
\hline \multirow[t]{3}{*}{ public education } & overall & 0.0465773 & 0.0178768 & $2.20 \mathrm{E}-08$ & 0.1605884 & $\mathrm{~N}=1142$ \\
\hline & between & & 0.0166878 & 0.0107698 & 0.1345486 & $\mathrm{n}=132$ \\
\hline & within & & 0.0065282 & 0.0116075 & 0.080467 & $\mathrm{~T}=8.65152$ \\
\hline \multirow[t]{3}{*}{ resource rent } & overall & 0.069023 & 0.1206953 & 0 & 0.7124102 & $\mathrm{~N}=1847$ \\
\hline & between & & 0.1134383 & 0 & 0.4881426 & $\mathrm{n}=132$ \\
\hline & within & & 0.0422454 & -0.1934626 & 0.3296232 & $\mathrm{~T}=13.9924$ \\
\hline \multirow[t]{3}{*}{ manufacture } & overall & 0.150221 & 0.1799946 & $1.66 \mathrm{E}-06$ & 1.545786 & $\mathrm{~N}=1651$ \\
\hline & between & & 0.176313 & 0.0002292 & 1.250382 & $\mathrm{n}=132$ \\
\hline & within & & 0.0420577 & -0.1074521 & 0.4456247 & $\mathrm{~T}=12.5076$ \\
\hline \multirow[t]{3}{*}{ agriculture } & overall & 0.1427335 & 0.1309526 & 0 & 0.6196861 & $\mathrm{~N}=1783$ \\
\hline & between & & 0.1296638 & 0 & 0.5412981 & $\mathrm{n}=132$ \\
\hline & within & & 0.0285795 & -0.0018374 & 0.2912675 & $\mathrm{~T}=13.5076$ \\
\hline \multirow[t]{3}{*}{ lngdpcapita } & overall & 8.687819 & 1.288765 & 5.846806 & 11.16942 & $\mathrm{~N}=1846$ \\
\hline & between & & 1.285605 & 5.876393 & 11.06253 & $\mathrm{n}=132$ \\
\hline & within & & 0.1489319 & 8.032617 & 9.563109 & $\mathrm{~T}=13.9848$ \\
\hline \multirow[t]{3}{*}{ schoolage } & overall & 0.5152618 & 0.1283044 & 0.0877251 & 0.7828103 & $\mathrm{~N}=1838$ \\
\hline & between & & 0.1244458 & 0.2857989 & 0.7320508 & $\mathrm{n}=132$ \\
\hline & within & & 0.0328315 & 0.1558916 & 0.8809171 & $\mathrm{~T}=13.9242$ \\
\hline \multirow[t]{3}{*}{ oldpopulation } & overall & 0.0764213 & 0.0502971 & 0.0044591 & 0.2204764 & $\mathrm{~N}=1848$ \\
\hline & between & & 0.0501886 & 0.0086851 & 0.1883664 & $\mathrm{n}=132$ \\
\hline & within & & 0.0053506 & 0.0407663 & 0.1118534 & $\mathrm{~T}=14$ \\
\hline \multirow[t]{3}{*}{ gdpgrowth } & overall & 0.025331 & 0.0421752 & -0.1754528 & 0.3303049 & $\mathrm{~N}=1846$ \\
\hline & between & & 0.0207922 & -0.0273782 & 0.1188897 & $\mathrm{n}=132$ \\
\hline & within & & 0.0367301 & -0.2070456 & 0.2367462 & $\mathrm{~T}=13.9848$ \\
\hline \multirow[t]{3}{*}{ openness } & overall & 0.8476624 & 0.4384633 & 0.1493284 & 4.146187 & $\mathrm{~N}=1813$ \\
\hline & between & & 0.4242345 & 0.2315079 & 3.264811 & $\mathrm{n}=132$ \\
\hline & within & & 0.1230053 & 0.0676905 & 1.729038 & $\mathrm{~T}=13.7348$ \\
\hline political stability & overall & 0.0342752 & 0.8924227 & -2.756399 & 1.576872 & $\mathrm{~N}=1447$ \\
\hline
\end{tabular}




\begin{tabular}{|c|c|c|c|c|c|c|}
\hline & between & & 0.8445778 & -1.923149 & 1.412548 & $\mathrm{n}=132$ \\
\hline & within & & 0.2942668 & -1.273218 & 1.608206 & $\mathrm{~T}=10.9621$ \\
\hline \multirow[t]{3}{*}{ regulatory quality } & overall & 0.1751986 & 0.8746884 & -2.272891 & 3.345251 & $\mathrm{~N}=1442$ \\
\hline & between & & 0.8439908 & -1.630469 & 1.816379 & $\mathrm{n}=132$ \\
\hline & within & & 0.2450257 & -1.150496 & 2.31369 & $\mathrm{~T}=10.9242$ \\
\hline \multirow[t]{3}{*}{ ruleoflaw } & overall & 0.0872166 & 0.9292883 & -1.741681 & 1.964045 & $\mathrm{~N}=1445$ \\
\hline & between & & 0.9109179 & -1.384658 & 1.889363 & $\mathrm{n}=132$ \\
\hline & within & & 0.1924041 & -1.404147 & 1.474483 & $\mathrm{~T}=10.947$ \\
\hline
\end{tabular}




\begin{tabular}{|c|c|c|c|c|}
\hline & $(1)$ & (2) & (3) & (4) \\
\hline resourcerent & $\begin{array}{l}-0.0316 * * \\
(0.00607)\end{array}$ & $\begin{array}{c}-0.0384 * * \\
(0.00731)\end{array}$ & $\begin{array}{c}-0.0354 * * \\
(0.00686)\end{array}$ & $\begin{array}{l}-0.0411 * * \\
(0.00714)\end{array}$ \\
\hline manufacture & $\begin{array}{c}0.0106^{*} \\
(0.00612)\end{array}$ & $\begin{array}{c}0.0107 \\
(0.00730)\end{array}$ & $\begin{array}{c}0.0140^{*} \\
(0.00737)\end{array}$ & $\begin{array}{c}0.0127^{*} \\
(0.00699)\end{array}$ \\
\hline agriculture & $\begin{array}{c}-0.111 * * \\
(0.0114)\end{array}$ & $\begin{array}{c}-0.0989 * * \\
(0.0137)\end{array}$ & $\begin{array}{c}-0.0884 * * \\
(0.0138)\end{array}$ & $\begin{array}{c}-0.0855^{* *} \\
(0.0145)\end{array}$ \\
\hline lngdpcapita & $\begin{array}{c}-0.0104 * * \\
(0.00267)\end{array}$ & $\begin{array}{c}-0.00833^{* *} \\
(0.00308)\end{array}$ & $\begin{array}{c}-0.00880^{* *} \\
(0.00306)\end{array}$ & $\begin{array}{c}-0.00909 * * \\
(0.00300)\end{array}$ \\
\hline schoolage & $\begin{array}{c}0.0103 \\
(0.00916)\end{array}$ & $\begin{array}{c}0.0123 \\
(0.00978)\end{array}$ & $\begin{array}{c}0.0119 \\
(0.00973)\end{array}$ & $\begin{array}{c}0.0132 \\
(0.00975)\end{array}$ \\
\hline oldpopulation & $\begin{array}{c}0.0571 \\
(0.0573)\end{array}$ & $\begin{array}{c}0.0377 \\
(0.0640)\end{array}$ & $\begin{array}{c}0.0476 \\
(0.0637)\end{array}$ & $\begin{array}{c}0.0294 \\
(0.0635)\end{array}$ \\
\hline gdpgrowth & $\begin{array}{c}-0.0147 * * \\
(0.00660)\end{array}$ & $\begin{array}{c}-0.0169 * * \\
(0.00739)\end{array}$ & $\begin{array}{c}-0.0193 * * \\
(0.00735)\end{array}$ & $\begin{array}{l}-0.0194 * * \\
(0.00735)\end{array}$ \\
\hline openness & $\begin{array}{c}-0.00355 \\
(0.00256)\end{array}$ & $\begin{array}{c}-0.00622 * * \\
(0.00293)\end{array}$ & $\begin{array}{l}-0.00502^{*} \\
(0.00290)\end{array}$ & $\begin{array}{c}-0.00569^{*} \\
(0.00293)\end{array}$ \\
\hline polstab & & $\begin{array}{c}-0.00189 \\
(0.00166)\end{array}$ & & \\
\hline resourcepolstab & & $\begin{array}{l}-0.0102 * \\
(0.00581)\end{array}$ & & \\
\hline manufacturepolstab & & $\begin{array}{c}0.00713 \\
(0.00447)\end{array}$ & & \\
\hline agripolstab & & $\begin{array}{c}0.00667 \\
(0.00574)\end{array}$ & & \\
\hline
\end{tabular}


regquality

resourceregquality

manufactureregquality

agriregquality

ruleoflaw

resourcerule

manufacturerule

agrirule

Observations

1016

0.157

828

0.165

shown in parentheses. * Significant at 10\%; ** significant at 5\%. All regressions include a constant term and year fixed effects (not reported).

$-0.00400 * *$

$(0.00183)$

$-0.0117^{*}$

(0.00706)

$-0.00118$

(0.00470)

$0.0319 * *$

(0.00972)

$-0.00481 * *$

(0.00214)

$-0.0200 * *$

(0.00729)

0.00253

(0.00460)

$0.0265 * *$

(0.00936)

830

0.177 


\begin{tabular}{|c|c|c|c|c|}
\hline & (1) & (2) & (3) & (4) \\
\hline resourcerent & $\begin{array}{l}-0.0220 * * \\
(0.00905)\end{array}$ & $\begin{array}{l}-0.0295^{* *} \\
(0.0113)\end{array}$ & $\begin{array}{l}-0.0325^{* *} \\
(0.0114)\end{array}$ & $\begin{array}{l}-0.0395 * * \\
(0.0128)\end{array}$ \\
\hline manufacture & $\begin{array}{l}0.0248 * * \\
(0.0102)\end{array}$ & $\begin{array}{l}0.0257^{* *} \\
(0.0119)\end{array}$ & $\begin{array}{l}0.0303 * * \\
(0.0119)\end{array}$ & $\begin{array}{l}0.0397 * * \\
(0.0120)\end{array}$ \\
\hline agriculture & $\begin{array}{l}-0.111 * * \\
(0.0172)\end{array}$ & $\begin{array}{l}-0.0878^{* *} \\
(0.0205)\end{array}$ & $\begin{array}{l}-0.0950^{* *} \\
(0.0211)\end{array}$ & $\begin{array}{l}-0.0770 * * \\
(0.0233)\end{array}$ \\
\hline lngdpcapita & $\begin{array}{l}-0.0167 * * \\
(0.00411)\end{array}$ & $\begin{array}{l}-0.0126^{* *} \\
(0.00490)\end{array}$ & $\begin{array}{l}-0.0136^{* *} \\
(0.00490)\end{array}$ & $\begin{array}{c}-0.0145^{* *} \\
(0.00465)\end{array}$ \\
\hline schoolage & $\begin{array}{l}0.0105 \\
(0.0128)\end{array}$ & $\begin{array}{l}0.0118 \\
(0.0137)\end{array}$ & $\begin{array}{l}0.0159 \\
(0.0137)\end{array}$ & $\begin{array}{l}0.0187 \\
(0.0136)\end{array}$ \\
\hline oldpopulation & $\begin{array}{l}0.472 * * \\
(0.121)\end{array}$ & $\begin{array}{l}0.410^{* *} \\
(0.144)\end{array}$ & $\begin{array}{l}0.323^{* *} \\
(0.141)\end{array}$ & $\begin{array}{l}0.332 * * \\
(0.142)\end{array}$ \\
\hline gdpgrowth & $\begin{array}{l}-0.0198^{* *} \\
(0.00999)\end{array}$ & $\begin{array}{l}-0.0229 * * \\
(0.0112)\end{array}$ & $\begin{array}{l}-0.0256^{* *} \\
(0.0112)\end{array}$ & $\begin{array}{l}-0.0244 * * \\
(0.0112)\end{array}$ \\
\hline openness & $\begin{array}{l}-0.00909 * * \\
(0.00405)\end{array}$ & $\begin{array}{l}-0.00957 * * \\
(0.00470)\end{array}$ & $\begin{array}{l}-0.00938^{* *} \\
(0.00470)\end{array}$ & $\begin{array}{c}-0.0114 * * \\
(0.00470)\end{array}$ \\
\hline polstab & & $\begin{array}{l}-0.00727 * * \\
(0.00291)\end{array}$ & & \\
\hline resourcepolstab & & $\begin{array}{l}-0.00358 \\
(0.00862)\end{array}$ & & \\
\hline manufacturepolstab & & $\begin{array}{l}0.0317 * * \\
(0.00783)\end{array}$ & & \\
\hline agripolstab & & $\begin{array}{l}0.0231 \\
(0.0147)\end{array}$ & & \\
\hline
\end{tabular}


resourceregquality

agriregquality

ruleoflaw

resourcerule

manufacturerule

agrirule

$0.0719 * *$

(0.0242)

Observations 528

0.175
436

Note: Public education spending is the dependent variable. Fixed effects model is used in all estimations. Point estimates are reported. Standard errors are shown in parentheses. * Significant at 10\%; ** significant at 5\%. All regressions include a constant term and year fixed effects (not reported). 


\section{REFERENCES}

Acemoglu, D. and Robinson, J. A. (2000). Political Losers as a Barrier to Economic Development. American Economic Review, Papers and Proceedings, 90 (2): 126-130.

Acemoglu, D. and Robinson, J. A. (2006). Economic Origins of Dictatorship and Democracy. Cambridge University Press.

Acemoglu, D. and Robinson, J. A. (2006). Economic Backwardness in Political Perspective. American Political Science Review, 100 (1):115-131.

Alesina, A., Devleeschauwer, A., Easterly, W., Kurlat, S. and Wacziarg, R. (2003). Fractionalization. Journal of Economic Growth, 8: 155-194.

Aslaksen, S. (2007). Corruption and Oil: Evidence from Panel Data. Unpublished Manuscript, University of Oslo.

Beck, T., Keefer P. E. and Clarke G. R. (2009). Database of Political Institutions (DPI 2009) Codebook. World Bank Economic Review.

Boschini, A. D., Pettersson, J. and Roine, J. (2007). Resource curse or not: a question of appropriability. The Scandinavian Journal of Economics, 109 (3): 593-617.

Brunnschweiler, C. N. (2008). Cursing the Blessings? Natural Resource Abundance, Institutions, and Economic Growth. World Development, 36: 399-419.

Bulte, E. H., Damania, R. and Deacon, R. T. (2005). Resource Intensity, Institutions and Development. World Development, 33: 1029-1044.

Busemeyer, M. R. (2007). Determinants of public education spending in 21 OECD democracies, 1980-2001. Journal of European Public Policy, 14 (4): 582-610.

Fernandez, R. and Rogerson, R. (1997). The determinants of public education expenditures: evidence from the States, 1950-1990. NBER Working Paper 5995, Cambridge, MA.

Heston, A., Summers, R. and Aten, B. (2009). Penn World Table Version 6.3. Center for International Comparisons of Production, Income and Prices at the University of Pennsylvania.

Galor, O., Moav, O. and Vollrath, D. (2009). Inequality in Land Ownership, the Emergence of Human Capital Promoting Institutions, and the Great Divergence. Review of Economic Studies, 76: 143-179.

Glaeser, E.L., La Porta, R. Lopez-De-Silanes, F. and Shleifer, A. (2004). Do Institutions Cause Growth? Journal of Economic Growth 9: 271-303. 
Karayalcin, C. and Ulubasoglu, M. A. (2010). Romes without Empires: Primate Cities, Political Competition, and Economic Growth. Working Paper, Florida International University.

Kaufmann, D., Kraay, A. and Mastruzzi, M. (2010). The Worldwide Governance Indicators: Methodology and Analytical Issues. World Bank Policy Research Working Paper No. 5430.

Lagerlof, N. P. and Tangeras, T. (2008). From rent seeking to human capital: a model where resource shocks cause transitions from stagnation to growth. Canadian Journal of Economics, 41(3): 760-780.

Matsuyama, K. (1992). Agricultural productivity, comparative advantage, and economic growth. Journal of Economic Theory, 58: 317-334.

Mehlum, H., Moene, K. and Torvik, R. (2006). Institutions and the resource curse. Economic Journal, 116: 1-20.

Poterba, J. M. (1997). Demographic Structure and the Political Economy of Public Education. Journal of Policy Analysis and Management, 16 (1): 48-66.

Sachs, J. and Warner, A. M. (1995). Natural Resource Abundance and Economic Growth. NBER Working Paper 5398.

Stijns, J.P. (2006). Natural Resource Abundance and Human Capital Accumulation. World Development, 34 (6): 1060-1083. 


\section{CHAPTER III}

\section{INTRODUCTION}

The effect of institutions on economic performance has remained a long-debated and unresolved issue in the literature. The examples of institutional reform failures in Africa, Latin America, the former Soviet Union in the 1980s and 1990s, and the recent cases of Afghanistan and Iraq support the view that radical changes in institutions do not necessarily have a positive effect on economic outcomes (Acemoglu, Cantoni, Johnson, and Robinson, 2011). According to Hayek (1960), institutions cannot be designed and have to emerge and form under natural and local conditions. A related view states that the externally-imposed institutions and reforms should be in harmony with the set of circumstances in the host countries (Berkowitz, Pistor and Richard, 2003a, b, Rodrik, 2007). Nevertheless, there are successful external institutional reform cases such as the post Second World War institutional transformations in Germany and Japan designed by the United States.

The related debate about the economic outcomes of the French Revolution has also not reached an agreement. On the one hand, some economic historians identify the French Revolution and following wars as an obstacle slowing down technology adoption and the industrial revolution in Continental Europe (Landes, 1969 and Crouzet, 2001). Specifically for the Dutch economy, Buyst and Mokyr (1990) argue that the Napoleonic wars hampered economic development in the Netherlands. On the other hand, the view that the enactment of the civil code, abolition of guilds and serfdom, and agricultural reforms caused by the French Revolution led the way to the industrial revolution and 
institutional enlightenment in Continental Europe suggests that French Revolution fostered economic development in parts of Europe affected by the Revolution and subsequent invasion (Olson, 1982 and Acemoglu, 2008).

In Chapter Three I investigate the impact of externally-imposed institutions on differences in regional economic growth within a country. Acemoglu, Cantoni, Johnson, and Robinson (2011) recently attempted to explore the impact of the French Revolution on German institutions and long-run German economic growth. To do this they compared the differences in the economic performance of those German states that were invaded by Napoleonic armies and that adopted French institutions with other German states that retained the particularly German legal and economic institutions throughout. They show that there remained a sustained difference in economic performance long after the invaders retreated. What remains to be shown is whether or not the differences are spurious.

I test this by comparing differences in the long-run economic performance of French regions. Since the French Revolution reforms and institutions were uniformly enforced across all regions in France, if, as hypothesized, it is found that there are significant regional growth differences in France, it would count as evidence against the hypothesis that all the regional economic development differences between invaded and non-invaded German polities were due to the French institutions. Adopting a strategy similar to the one employed for Germany by Acemoglu et al. (2011), I use the urbanization rates of the 95 departments in France as a proxy for economic development. The data for city and department size are collected from statistics compiled by Chandler (1987) and Lahmeyer 
(n.d.). Urbanization rates are computed for the years 1810 and 1901. By using a simple statistical t-test, I show that significantly different urbanization rates were observed in the French departments as well in both periods. This finding of different urbanization rates among the French regions suggests that the departments went through different economic development experiences during the Napoleonic period (1810) and in the postNapoleonic period (1901). Furthermore, a difference-in-differences estimation is done to examine whether or not there is a treatment effect causing the regional growth differences in France. If uniform or similar urbanization rates across French departments had been experienced this could have suggested that French Revolution reforms and institutions were effective in causing similar growth rates across regions. The result of regional economic prosperity differences across French departments in the periods after the launch of the French Revolution indicates that all the variation in economic growth between the French-invaded and non-invaded German polities cannot be attributed to the French Revolution reforms and institutions.

The rest of the paper is organized as follows. Section 2 presents an overview of the history and fundamental reasons of the French Revolution. Section 3 provides a summary of the Acemoglu, Cantoni, Johnson, and Robinson (2011) paper and empirical evidence from Germany. Section 4 presents the empirical analysis, and section 5 concludes.

\section{HISTORICAL OVERVIEW OF THE FRENCH REVOLUTION}

The French Revolution took place under negative economic conditions. The monarchical authority was in bankruptcy. Agricultural production in northern France was damaged by 
poor weather conditions, causing the price of bread, the main staple food for most of the population, to rise. Since consumers spent the majority of their earnings on food the demand for other goods decreased (Doyle, 2001). Moreover, the manufacturing sector was negatively affected by British competition and the ensuing lower prices under the commercial treaty of 1786 . In addition to this, the unemployment rate in France was increasing, and an unexpectedly cold winter hampered production by mills and bulk transport.

Before the French Revolution social life and the economy were controlled by a few dominant groups. The landlords imposed a form of serfdom by putting peasants under the burden of heavy taxes and tributes, limiting the mobility of peasants, and hindering the emergence of a free labor market. The urban oligarchy dominant in trade and production sectors strictly controlled important occupations for their own economic benefit by restricting new entry into professions and use of new technology (Doyle, 2001). In rural areas, the nobility and Church clergy had the privilege of not paying taxes, and they were not subject to the same laws and courts as peasants, which created an inequitable political and economic atmosphere.

The long-term and widespread economic crisis and social inequality led in 1789 to a meeting of the Estates-General for the first time in 175 years. The Estates-General took the name National Constituent Assembly with the promise of gathering more political power in itself and writing a constitution. It abolished feudalism, the nobility's special privileges and rights, and the Church clergy's authority of taxation. The constitution that was finalized on September 29, 1791 declared France as a constitutional monarchy. The 
abolition of guilds followed. In 1804 Napoleon declared himself as emperor, and between 1799 and 1815 he pursued a widespread invasion in Continental Europe.

The French Revolution was triggered by social injustice and economic crisis, and it caused removal of the institutions of the ancien regime, and had profound political and economic consequences. The abolition of serfdom and guilds, and agricultural reforms initiated the emergence of mobile and free labor markets and manufacturing activities. The enactment of French civil code, which established the principle of equality before the law, and the establishment of commercial courts paved the way to a legal environment and a system favoring new businesses, entrepreneurial activities and industrialization.

\section{ACEMOGLU, CANTONI, JOHNSON, AND ROBINSON (2011) PAPER}

Acemoglu, Cantoni, Johnson, and Robinson (2011) use evidence on differences in German regional growth to test the hypothesis that radical and externally-imposed reforms of the French Revolution caused higher and more rapid economic growth in the German polities where they were imposed. Acemoglu et al. (2011) investigate the relationship between the length of French Revolutionary armies' occupation (treatment variable) and economic prosperity in a reduced-form analysis. Further, in a two-stage least squares framework they analyze impact of the timing and enforcement length of main French Revolution reforms such as the enactment of French civil code, agricultural reforms and abolition of guilds on institutional transformation and long-run economic development across German polities. They adopt urbanization rates as the proxy measure for economic prosperity, and thus as their dependent variable in the benchmark 
estimations. The treatment variable that Acemoglu et al. (2011) use is defined as the number of years between 1792 and 1815 that the polity in question was under invasion of Napoleonic armies.

Acemoglu et al. (2011) use OLS estimation to examine the relationship between French treatment and urbanization rates across German polities. The time periods they use in the data panel are $1700,1750,1800,1850,1875$, and 1900 . They provide evidence through OLS estimation and joint significance tests of post-treatment years, that in those German states invaded by Napoleonic armies and where French Revolution institutional reforms were enforced a faster urbanization took place after 1850. They argue that French invasion and Revolution reforms in occupied states were effective in the launch of Continental Europe's industrial revolution in the second half of the $19^{\text {th }}$ century. For robustness check, they control for interactions between time dummy variables and various time-invariant variables such as religion, longitude, and distance to Paris. These controls do not change the results of the OLS estimation too much.

In the second part of their analysis, Acemoglu et al. (2011) use a two-stage least squares method to estimate the impact of French occupation on urbanization rates through the timing and length of enforcement of Revolution reforms. For the first stage, they construct a reform index by adding the number of years each of the 4 important Revolution reforms (Code Napoleon, abolition of serfdom, agrarian reforms, and abolition of guilds) had been implemented in a polity and dividing by 4 . They examine the relationship between the time period of French presence and the reform index. Then, in the second stage they estimate the effect of the reform index on urbanization rate. As 
in the reduced-form estimation, they conclude that the institutional reforms caused a more rapid economic growth especially after 1850 .

Acemoglu et al. (2011), as a result of their two-fold empirical analysis, argue that the French occupation in German polities launched radical and externally-imposed institutional reforms such as imposition of the civil code, agricultural reforms, commercial courts, and abolition of guilds which caused the emergence of a state structure supporting an industrializing society, a relatively free labor market, commercial and manufacturing businesses. Hence the French invasion, and externally-imposed Revolution reforms and institutions gave way to more rapid long-run economic development in occupied German polities, and to regional economic growth differences within Germany.

Nevertheless, Acemoglu et al. (2011) mention some caveats about their findings. They acknowledge that higher economic growth was observed in German polities where French Revolution institutions were imposed mainly after 1850. Moreover, they recognize that there is limited historical data available, and they argue the results found regarding a limited time period may not be generalized for other time periods.

\section{EMPIRICAL EVIDENCE}

\section{Data Details and Empirical Strategy}

To reexamine the issue, I propose to look at the growth experience of French 'departments' in the same period. The 'departments' in France are considered as the appropriate geographical units to identify long-run regional growth differences in the 
empirical analysis. The administrative area of France is divided into 95 departments. The proxy for economic development is the urbanization rate, which is commonly defined in the literature as the fraction of the population living in cities with more than 5000 inhabitants (Chandler, 1987, and Bairoch, Batou and Chevre, 1988). Urbanization rates across French regions are calculated from city and department population statistics from Chandler (1987) and Lahmeyer's population database (n.d.).

One of the main points of interest of the present paper is to develop a critical examination of the findings of Acemoglu et al. (2011) where the period of analysis is 1700-1900. Moreover, because of data availability urbanization rates at the department level are computed for the years 1810 and 1901 on the basis of population statistics of 697 cities. The departments are divided into 16 border and 79 interior departments. Paris and its surrounding area, and Northeast-East regions close to Belgium, Netherlands, Luxembourg, Germany, and Switzerland are defined as border departments. The division of French departments into two sets is motivated by the finding in the economic history literature that the industrial revolution in continental Europe was initially a regional development that was determined by the availability of coal and other minerals that served as inputs in the fledgling industrial sector (Barnes et al., 1966, Cameron and Neal, 2003, Clapham, 1936, and Pollard, 1981). The regions where these inputs were readily available formed a corridor that ran from parts of Belgium through northeastern France, down to the border of France with Switzerland. Much of Germany occupied by Napoleonic armies also happens to be part of this mineral-rich region in northern Europe, suggesting a probable mechanism for differential growth within Germany independent of the institutional framework imposed. 
In the following two subsections statistical tools and difference-in-differences estimation are used to demonstrate the variation in economic development among departments in France. In the Appendix, Table1 shows the department names, capital city of each department, whether it is classified as an interior or border department, and urbanization rates for 1810 and 1901 .

Classical Hypothesis Testing In this section a simple t-test is conducted to test the null hypothesis that the mean urbanization rates of border and interior departments are equal to each in the years 1810 and 1901. In the year 1810 urbanization data are available for 87 departments because of missing population statistics. Table 2 and Table 3 in the Appendix show descriptive statistics of urbanization in 1810 and 1901 grouped by border and interior departments. It is found out that in the 95 percent confidence interval we can reject the null hypothesis for year 1810 at 88.21 percent level, and for year 1901 at 99.58 percent. Hence, statistical test results show that different urbanization rates were experienced across departments, suggesting that French departments went through different economic growth experiences in the short and the long-run after the French Revolution. The result of different urbanization rates indicates that within France significant regional economic growth differences occurred after the Revolution and imposition of institutional reforms. 


\section{Difference-in-differences Estimation}

In their paper Acemoglu et al. (2011) argue that some German polities grew faster than others because these polities were subjected to the treatment of French Revolution reforms and institutions through French invasion while others did not. One way to test this argument is to carry out a difference-in-differences regression for the French case. As it is already shown in the previous section that there were differences in regional growth in France, let us apply the logic of the argument in Acemoglu et al. (2011) without the specification of the treatment in France and examine if we can find the existence of a treatment effect for economic growth differences in France. The benchmark regression is as follows:

$u_{i t}=\beta_{0}+\beta_{1} d_{i t}+\beta_{2} p_{i t}+\beta_{3}\left(d_{i t} * p_{i t}\right)+\varepsilon_{i t}$

where $u_{i t}$ is the urbanization rate in department $i$ at time $t, d_{i t}$ is a region dummy variable taking up the value 1 if the department is a border department, $p_{i t}$ is a time dummy variable, and it is equal to 1 if the period is year $1901,\left(d_{i t} * p_{i t}\right)$ is an interaction term, and $\varepsilon_{i t}$ is a disturbance term. The purpose of running a difference-in-differences regression is (taking into account the data limitations) to identify the existence of a treatment effect that caused the regional economic prosperity differences between the border departments and interior departments in France.

Table 4 depicts the regression results. The coefficients are positive and statistically significant. The results suggest that there is evidence of some treatment effect across French departments as well, similar to the case of the treatment effect in German polities. 
Since, in France, the French Revolution reforms and institutions were enforced uniformly across all regions, the treatment effect cannot possibly due to differences in institutions.

This finding count as a counter-argument against the argument of Acemoglu et al. (2011) that it was the French Revolution institutions and reforms that caused higher economic growth in the German polities invaded by French armies compared to other polities which were not invaded. One possible explanation for the differences in regional growth observed both in Germany and France could be the mining of coal and other minerals, and its positive impact on subsequent industrialization in continental Europe as suggested by Barnes et al. (1966), Cameron and Neal (2003), and Pollard (1981).

\section{CONCLUSION}

The French Revolution resulted in a large-scale and long-term institutional transformation in Europe. It permanently changed the social and political setting in France, and then in Continental Europe through invasions of French Revolutionary armies and Napoleon. Whether externally-imposed institutions and specifically French Revolution reforms positively affected economic development is a long-debated topic. Acemoglu et al. (2011) provide empirical evidence that externally-imposed, radical French Revolution institutions caused a faster long-run economic growth in the invaded German polities compared to non-invaded polities especially after 1850 . The present paper proposes a counter-argument to Acemoglu et al. (2011) saying that differences in institutions may not have been the only or leading reason in causing regional economic growth differences. 
Urbanization rates at the French department level are used as proxy for economic development for the years 1810 and 1901. The 95 departments are divided into two subgroups as interior and border departments. By using a statistical t-test, we can comfortably reject the null hypothesis that average urbanization rates of interior and border departments were equal, indicating that regional economic growth differences were experienced within France. This result suggests that even though French Revolution institutions were imposed uniformly within France, they did not cause the departments to experience similar economic growth trends both in the short-run and long-run after the onset of French Revolution.

Then, a difference-in-differences estimation is used to identify the existence of a treatment effect responsible for regional growth differences in France. The finding of a treatment effect provides a counter-argument to Acemoglu et al. (2011) where they argue that externally-imposed Revolution institutions and reforms caused a faster long-run economic development in occupied German polities compared to non-occupied German polities which retained particularly German institutions and law.

If it had not been for the French Revolution institutions and reforms, then what could cause the higher economic growth rates in the border departments of France? The coal mining and proto-industrialization activities in Northeast-East France where border departments cluster might have fostered industrial development and economic prosperity in these regions (Barnes et al, 1966, Pollard, 1981, and Cameron and Neal, 2003). In fact, coal mining and proto-industrialization also played an important role in those German polities which were invaded by the French Revolutionary and then Napoleonic armies, 
and where French Revolution institutional reforms were implemented. Unfortunately, we do not have access to historical coal and other mines data at the regional level ${ }^{11}$. If we had such an access we could have tested this argument empirically. It is certainly the case that the findings of this paper would be strengthened if more detailed, micro-level historical data related to coal mining, railway construction, and infant industrialization were made available.

${ }^{11}$ Detailed historical European statistics at the country level can be found in Mitchell (1981). 
Table 8. Urbanization in French Departments

\begin{tabular}{|c|c|c|c|c|c|}
\hline department & dept.no & capital & $\begin{array}{c}\text { urbanization } \\
1810 \\
\end{array}$ & $\begin{array}{c}\text { urbanization } \\
1901\end{array}$ & region \\
\hline Ain & 1 & Bourg-en-Bresse & 2.36 & 7.29 & interior \\
\hline Aisne & 2 & Laon & 5.56 & 19.42 & interior \\
\hline $\begin{array}{l}\text { Allier } \\
\text { Alpes-de-Haute- }\end{array}$ & 3 & Moulins & 10.64 & 21.21 & interior \\
\hline Provence & 4 & Digne & 3.88 & 12.87 & interior \\
\hline Alpes (Hautes-) & 5 & Gap & 6.91 & 10.05 & interior \\
\hline Alpes-Maritimes & 6 & Nice & NA & 60.91 & interior \\
\hline Ardèche & 7 & $\begin{array}{l}\text { Privas } \\
\text { Charleville- }\end{array}$ & 1.96 & 9.47 & interior \\
\hline Ardennes & 8 & Mézières & 8.74 & 17.40 & border \\
\hline Ariège & 9 & Foix & 2.88 & 8.55 & interior \\
\hline Aube & 10 & Troyes & 11.78 & 25.22 & interior \\
\hline Aude & 11 & Carcassonne & 10.79 & 19.01 & interior \\
\hline Aveyron & 12 & Rodez & 3.56 & 12.12 & interior \\
\hline Bouches-du-Rhône & 13 & Marseille & 50.08 & 80.27 & interior \\
\hline Calvados & 14 & Caen & 13.89 & 19.82 & interior \\
\hline Cantal & 15 & Aurillac & 4.36 & 7.59 & interior \\
\hline Charente & 16 & Angoulême & 4.64 & 16.30 & interior \\
\hline Charente-Maritime & 17 & La Rochelle & 9.47 & 20.95 & interior \\
\hline Cher & 18 & Bourges & 10.54 & 19.33 & interior \\
\hline Corrèze & 19 & Tulle & 5.88 & 9.92 & interior \\
\hline Corse & 20 & Ajaccio & 10.40 & 15.97 & interior \\
\hline Côte-d'Or & 21 & Dijon & 8.50 & 23.53 & interior \\
\hline Côtes-d'Armor & 22 & Saint-Brieuc & 3.81 & 7.88 & interior \\
\hline Creuse & 23 & Guéret & 0 & 2.56 & interior \\
\hline Dordogne & 24 & Périgueux & 5.52 & 10.57 & interior \\
\hline Doubs & 25 & Besançon & 12.38 & 27.00 & border \\
\hline Drôme & 26 & Valence & 11.68 & 19.31 & interior \\
\hline Eure & 27 & Évreux & 5.49 & 11.14 & interior \\
\hline Eure-et-Loir & 28 & Chartres & 9.95 & 14.71 & interior \\
\hline Finistère & 29 & Quimper & 11.13 & 24.71 & interior \\
\hline Gard & 30 & Nîmes & 20.09 & 29.97 & interior \\
\hline Garonne (Haute-) & 31 & Toulouse & 14.23 & 33.40 & interior \\
\hline Gers & 32 & Auch & 3.04 & 5.83 & interior \\
\hline Gironde & 33 & Bordeaux & 21.42 & 41.91 & interior \\
\hline Hérault & 34 & Montpellier & 25.04 & 36.47 & interior \\
\hline Ille-et-Vilaine & 35 & Rennes & 13.03 & 21.28 & interior \\
\hline Indre & 36 & Châteauroux & 8.80 & 13.57 & interior \\
\hline Indre-et-Loire & 37 & Tours & 7.98 & 19.28 & interior \\
\hline
\end{tabular}




\begin{tabular}{|c|c|c|c|c|c|}
\hline Isère & 38 & Grenoble & 8.47 & 20.74 & interion \\
\hline Jura & 39 & Lons-le-Saunier & 4.17 & 14.50 & border \\
\hline Landes & 40 & Mont-de-Marsan & 0 & 7.51 & interior \\
\hline Loir-et-Cher & 41 & Blois & 13.53 & 15.03 & interior \\
\hline Loire & 42 & Saint-Étienne & 16.33 & 39.31 & interior \\
\hline Loire (Haute-) & 43 & Le Puy & 4.85 & 6.56 & interior \\
\hline Loire-Atlantique & 44 & Nantes & 20.51 & 31.05 & interion \\
\hline Loiret & 45 & Orléans & 18.81 & 23.89 & interion \\
\hline Lot & 46 & Cahors & 4.36 & 6.18 & interior \\
\hline Lot-et-Garonne & 47 & Agen & 8.97 & 16.33 & interior \\
\hline Lozère & 48 & Mende & 3.83 & 5.66 & interior \\
\hline Maine-et-Loire & 49 & Angers & 10.99 & 22.93 & interior \\
\hline Manche & 50 & Saint-Lô & 3.93 & 16.22 & interior \\
\hline Marne & 51 & Châlons-sur-Marne & 16.60 & 37.93 & border \\
\hline Marne (Haute-) & 52 & Chaumont & 8.34 & 17.26 & interion \\
\hline Mayenne & 53 & Laval & 7.45 & 12.94 & interior \\
\hline Meurthe-et-Moselle & 54 & Nancy & 15.65 & 33.05 & border \\
\hline Meuse & 55 & Bar-le-Duc & 3.34 & 13.79 & border \\
\hline Morbihan & 56 & Vannes & 6.95 & 16.49 & interior \\
\hline Moselle & 57 & Metz & 11.65 & 23.88 & border \\
\hline Nièvre & 58 & Nevers & 7.94 & 11.21 & interior \\
\hline Nord & 59 & Lille & 29.32 & 48.75 & border \\
\hline Oise & 60 & Beauvais & 6.83 & 14.81 & interior \\
\hline Orne & 61 & Alençon & 6.47 & 11.41 & interior \\
\hline Pas-de-Calais & 62 & Arras & 13.47 & 30.24 & border \\
\hline Puy-de-Dôme & 63 & Clermont-Ferrand & 11.75 & 16.06 & interion \\
\hline Pyrénées-Atlantiques & 64 & $\mathrm{Pau}$ & 7.86 & 20.99 & interior \\
\hline Pyrénées (Hautes-) & 65 & Tarbes & 4.13 & 16.15 & interior \\
\hline Pyrénées-Orientales & 66 & Perpignan & 9.84 & 17.07 & interior \\
\hline Rhin (Bas-) & 67 & Strasbourg & 14.93 & 31.03 & border \\
\hline Rhin (Haut-) & 68 & Colmar & 6.92 & 30.67 & border \\
\hline Rhône & 69 & Lyon & 42.77 & 60.68 & interior \\
\hline Saône (Haute-) & 70 & Vesoul & 1.76 & 3.64 & interior \\
\hline Saône-et-Loire & 71 & Mâcon & 6.67 & 19.83 & interior \\
\hline Sarthe & 72 & Le Mans & 5.78 & 17.46 & interior \\
\hline Savoie & 73 & Chambéry & 2.22 & 14.29 & interior \\
\hline Savoie (Haute-) & 74 & Annecy & NA & 7.54 & interior \\
\hline Paris & 75 & Paris & 98.33 & 100.00 & border \\
\hline Seine-Maritime & 76 & Rouen & 23.05 & 45.10 & interior \\
\hline Seine-et-Marne & 77 & Melun & 8.40 & 19.43 & interion \\
\hline Yvelines & 78 & Versailles & 7.84 & 39.33 & interior \\
\hline
\end{tabular}




\begin{tabular}{lllccc} 
Sévres (Deux-) & 79 & Niort & 5.75 & 8.47 & interior \\
Somme & 80 & Amiens & 12.34 & 20.68 & interior \\
Tarn & 81 & Albi & 10.40 & 22.55 & interior \\
Tarn-et-Garonne & 82 & Montauban & 10.81 & 15.59 & interior \\
Var & 83 & Toulon & 15.94 & 47.43 & interior \\
Vaucluse & 84 & Avignon & 24.41 & 35.37 & interior \\
Vendée & 85 & La Roche-sur-Yon & 4.71 & 9.47 & interior \\
Vienne & 86 & Poitiers & 11.76 & 18.05 & interior \\
Vienne (Haute-) & 87 & Limoges & 8.51 & 25.01 & interior \\
Vosges & 88 & Épinal & 7.35 & 16.39 & border \\
Yonne & 89 & Auxerre & 6.42 & 10.53 & interior \\
Belfort (Territoire de) & 90 & Belfort & NA & 35.32 & interior \\
Essonne & 91 & Évry & NA & 16.95 & interior \\
Hauts-de-Seine & 92 & Nanterre & NA & 90.18 & border \\
Seine-Saint-Denis & 93 & Bobigny & NA & 79.04 & border \\
Val-de-Marne & 94 & Créteil & NA & 81.41 & border \\
Val-d'Oise & 95 & Pontoise & NA & 18.79 & interior \\
\hline \hline
\end{tabular}

Note: The missing urbanization rates for eight departments in 1810 are shown with 'NA'.

Table 9. Urbanization in 1810

\begin{tabular}{lcccccc} 
Department & Obs. & Mean & Standard Error & Standard Deviation & $95 \%$ Conf. & Interval \\
\hline Border & 13 & 18.681 & 6.893 & 24.854 & 3.662 & 33.700 \\
Interior & 74 & 10.013 & 0.962 & 8.275 & 8.01 & 11.93 \\
Combined & 87 & 11.308 & 1.330 & 12.408 & 8.664 & 13.953 \\
Difference & & 8.668 & 6.960 & & -6.423 & 23.759 \\
\hline
\end{tabular}

Note: Descriptive statistics for urbanization in 1810 at the department level.

Table 10. Urbanization in 1901

\begin{tabular}{lcccccr} 
Department & Obs. & Mean & Standard Error & Standard Deviation & $95 \%$ Conf. & Interval \\
\hline Border & 16 & 42.204 & 7.218 & 28.874 & 26.818 & 57.589 \\
Interior & 79 & 20.123 & 1.536 & 13.648 & 17.066 & 23.180 \\
Combined & 95 & 23.842 & 1.938 & 18.884 & 19.995 & 27.689 \\
Difference & & 22.081 & 7.380 & & 6.466 & 37.696 \\
\hline
\end{tabular}

Note: Descriptive statistics for urbanization in 1901 at the department level. 
Table 11. Difference-in-Differences Estimation

\begin{tabular}{|c|c|}
\hline & $\begin{array}{c}\text { (1) } \\
\text { urbanization }\end{array}$ \\
\hline$d_{i t}$ & $\begin{array}{l}0.0867^{*} \\
(0.0448)\end{array}$ \\
\hline$p_{i t}$ & $\begin{array}{l}0.101 * * \\
(0.0241)\end{array}$ \\
\hline$d_{i t} * p_{i t}$ & $\begin{array}{l}0.134^{* *} \\
(0.0606)\end{array}$ \\
\hline constant & $\begin{array}{l}0.100 * * \\
(0.0173)\end{array}$ \\
\hline $\begin{array}{l}\text { Observations } \\
R^{2}\end{array}$ & $\begin{array}{c}182 \\
0.268\end{array}$ \\
\hline
\end{tabular}

\section{REFERENCES}

Acemoglu, D. (2008). Oligarchic vs. Democratic Societies. Journal of the European Economic Association, 6: 1-44.

Acemoglu, D., Cantoni D., Johnson S., and Robinson J. A. (2011). The Consequences of Radical Reform: The French Revolution. American Economic Review, 101 (7): 1-30.

Bairoch, P., Batou J., and Ch`evre P. (1988). La Population des villes Europenees, 8001850: Banque de Donn'ees et Analyse Sommaire des R'esultats. Geneva; Droz.

Barnes, T. G., Blum J., and Cameron R. (1966). The European World since 1815: Triumph and Transition. Little, Brown and Company.

Berkowitz, D., Pistor K., and Richard J.-F. (2003a). The Transplant Effect. American Journal of Comparative Law, 51: 163-204.

Berkowitz, D., Pistor K., and Richard J.-F. (2003b). Economic Development, Legality and the Transplant Effect. European Economic Review, 47: 165-195.

Buyst, E. and Mokyr J. (1990). Dutch Manufacturing and Trade during the French Period (1975-1814) in a Long Term Perspective in Erik Aerts and Francois Crouzet eds. Economic Effects of the French Revolutionary Wars. Leuven; Leuven University Press.

Cameron, R. and Neal L. (2003). A Concise Economic History of the World From Paleolithic Times to the Present. Fourth Edition, New York, Oxford University Press. 
Chandler, T. (1987). Four Thousand Years of Urban Growth: A Historical Census. St. David's University Press, Lewiston/Queenston.

Clapham, J. H. (1936). The Economic Development of France and Germany 1815-1914. Cambridge University Press.

Doyle, W. (2001). The French Revolution: A Very Short Introduction. Oxford; Oxford University Press.

Hayek, F. (1960). The Constitution of Liberty. Chicago; University Of Chicago Press.

Lahmeyer, J. (n.d.) Population statistics: historical demography of all countries, their divisions and towns. http://www.populstat.info/.

Mitchell, B. R. (1981). European Historical Statistics, 1750-1975, Facts on File. New York.

Olson, M. (1982). The Rise and Decline of Nations: Economic Growth, Stagflation, and Social Rigidities. New Haven; Yale University Press.

Pollard, S. (1981). Peaceful Conquest: The Industrialization of Europe 1760-1970. Oxford University Press.

Rodrik, D. (2007). One Economics, Many Recipes: Globalization, Institutions, and Economic Growth. Princeton; Princeton University Press. 


\section{APPENDIX TO CHAPTER I}

\section{A.1. Socially Optimal Tax Rate}

As follows from (1), (18), (20) and (21), in period $t+1$ the aggregate output, $Q_{t+1}$, is written as the following,

$$
\begin{aligned}
& \begin{array}{l}
Q_{t+1}=Q\left(Q_{t}, \tau_{t}, N, Z\right)=Q^{M}\left(Q_{t}, \tau_{t}, \delta^{M}\left(Q_{t}, \tau_{t}, N, Z\right), \delta^{N}\left(Q_{t}, \tau_{t}, N, Z\right), N\right)+ \\
\qquad Q^{A}\left(\delta^{M}\left(Q_{t}, \tau_{t}, N, Z\right), \delta^{N}\left(Q_{t}, \tau_{t}, N, Z\right), Z\right)
\end{array} \\
& \begin{array}{l}
Q_{t+1}= \\
{[(1-}
\end{array} \\
& \begin{array}{l}
\left.\left.\tau_{t}\right) a Q_{t}\right]^{\alpha}\left[\delta^{M}\left(Q_{t}, \tau_{t}, N, Z\right) h\left(\tau_{t} a Q_{t}\right)\right]^{\theta}\left[N^{\beta}\left[\delta^{N}\left(Q_{t}, \tau_{t}, N, Z\right) h\left(\tau_{t} a Q_{t}\right)\right]^{1-\beta}\right]^{(1-\alpha-\theta)}+ \\
Z^{\gamma}\left(1-\delta^{N}\left(Q_{t}, \tau_{t}, N, Z\right)-\delta^{M}\left(Q_{t}, \tau_{t}, N, Z\right)\right)^{1-\gamma}
\end{array} \\
& \begin{array}{c}
\partial Q_{t+1} / \partial \tau_{t}=-a Q_{t} \alpha Q_{t+1}^{M} K_{t+1}^{-1}+a Q_{t} \theta Q_{t+1}^{M}\left[h\left(\tau_{t} a Q_{t}\right)\right]^{-1} h^{\prime}\left(\tau_{t} a Q_{t}\right)+a Q_{t}(1-\beta)(1- \\
\alpha-\theta) Q_{t+1}^{M}\left[h\left(\tau_{t} a Q_{t}\right)\right]^{-1} h^{\prime}\left(\tau_{t} a Q_{t}\right)=0
\end{array} \\
& \partial Q_{t+1} / \partial \tau_{t}=a Q_{t}\left[-R\left(Q_{t}, \tau_{t}^{*}, N, Z\right)+\delta_{t+1}^{M *} w_{t+1}^{M} h^{\prime}\left(\tau_{t}^{*} a Q_{t}\right)+\right. \\
& \left.\rho_{t+1} \delta_{t+1}^{N *} w_{t+1}^{N} h^{\prime}\left(\tau_{t}^{*} a Q_{t}\right)\right]=0
\end{aligned}
$$

Then, it follows that

$$
\begin{aligned}
& {\left[\delta^{M *}\left(Q_{t}, \tau_{t}^{*}, N, Z\right) w_{t+1}^{M} h^{\prime}\left(\tau_{t}^{*} a Q_{t}\right)\right]+\left[\rho_{t+1} \delta^{N *}\left(Q_{t}, \tau_{t}^{*}, N, Z\right) w_{t+1}^{N} h^{\prime}\left(\tau_{t}^{*} a Q_{t}\right)\right]=} \\
& R\left(Q_{t}, \tau_{t}^{*}, N, Z\right)
\end{aligned}
$$

Hence, $\tau_{t}^{*}$ equates the marginal returns to human capital employed in the natural resources sector and manufacturing sector to the marginal return to physical capital. This shows that $\tau_{t}^{*}$ is the socially optimal tax rate which both maximizes the aggregate output and achieves the efficient level of investment in public education. 
A.2. Preferred Tax Rate of the Manufacturers

As follows from (6), (20), (22) and (25), the second period income function of a manufacturer can be written more explicitly,

$y_{t+1}^{M}=h_{t+1} \theta K_{t+1}^{\alpha}\left(\delta_{t+1}^{M} h_{t+1}\right)^{\theta-1} N^{\beta(1-\alpha-\theta)}\left(\delta_{t+1}^{N} h_{t+1}\right)^{(1-\beta)(1-\alpha-\theta)}+(1-$

$\left.\tau_{t}^{M}\right) b_{t}^{M}\left[\alpha K_{t+1}^{\alpha-1}\left(\delta_{t+1}^{M} h_{t+1}\right)^{\theta} N^{\beta(1-\alpha-\theta)}\left(\delta_{t+1}^{N} h_{t+1}\right)^{(1-\beta)(1-\alpha-\theta)}\right]$

The cost of increasing human capital is the increase in the tax rate. Following from (15), we can express the second period physical capital investment as;

$$
K_{t+1}=\left(1-\tau_{t}^{M}\right) a Q_{t}
$$

Since $h_{t+1}=h\left(e_{t}\right)$ and as follows from (16), the efficiency units of human capital function can be written as

$h_{t+1}=h\left(e_{t}\right)=h\left(\tau_{t}^{M} a Q_{t}\right)$

Now we can rewrite the second period income function of the manufacturers as

$$
\begin{aligned}
& y_{t+1}^{M}= \\
& {[\theta(1-} \\
& \left.\left.\tau_{t}^{M}\right)^{\alpha}\left(a Q_{t}\right)^{\alpha}\left[h\left(\tau_{t}^{M} a Q_{t}\right)\right]^{(1-\alpha-\beta+\alpha \beta+\theta \beta)}\left(\delta_{t+1}^{M}\right)^{\theta-1} N^{\beta(1-\alpha-\theta)}\left(\delta_{t+1}^{N}\right)^{(1-\beta)(1-\alpha-\theta)}\right]+ \\
& {\left[\alpha b_{t}^{M}(1-\right.} \\
& \left.\left.\tau_{t}^{M}\right)^{\alpha}\left(a Q_{t}\right)^{\alpha-1}\left[h\left(\tau_{t}^{M} a Q_{t}\right)\right]^{(1-\alpha-\beta+\alpha \beta+\theta \beta)}\left(\delta_{t+1}^{M}\right)^{\theta} N^{\beta(1-\alpha-\theta)}\left(\delta_{t+1}^{N}\right)^{(1-\beta)(1-\alpha-\theta)}\right]
\end{aligned}
$$

Simplifying this expression further;

$y_{t+1}^{M}=$

$(1-$ 


$$
\begin{aligned}
& \left.\tau_{t}^{M}\right)^{\alpha}\left(a Q_{t}\right)^{\alpha}\left[h\left(\tau_{t}^{M} a Q_{t}\right)\right]^{(1-\alpha-\beta+\alpha \beta+\theta \beta)}\left(\delta_{t+1}^{M}\right)^{\theta} N^{\beta(1-\alpha-\theta)}\left(\delta_{t+1}^{N}\right)^{(1-\beta)(1-\alpha-\theta)}\left[\left(\theta\left(\delta_{t+1}^{M}\right)^{-1}\right)+\right. \\
& \left.\left(\alpha b_{t}^{M}\left(a Q_{t}\right)^{-1}\right)\right]
\end{aligned}
$$

Now, we can take the derivative of the second period income function with respect to the preferred tax rate of the manufacturers, $\tau_{t}^{M}$, and get both the benefit and the cost of supporting human capital accumulation for the manufacturers.

$$
\begin{aligned}
& \frac{\partial y_{t+1}^{M}}{\partial \tau_{t}^{M}}= \\
& (1- \\
& \left.\tau_{t}^{M}\right)^{\alpha}\left(a Q_{t}\right)^{\alpha}\left[h\left(\tau_{t}^{M} a Q_{t}\right)\right]^{(1-\alpha-\beta+\alpha \beta+\theta \beta)}\left(\delta_{t+1}^{M}\right)^{\theta} N^{\beta(1-\alpha-\theta)}\left(\delta_{t+1}^{N}\right)^{(1-\beta)(1-\alpha-\theta)}\{\{[(1- \\
& \left.\alpha-\beta+\alpha \beta+\theta \beta) h^{\prime}\left(\tau_{t}^{M} a Q_{t}\right)\left[h\left(\tau_{t}^{M} a Q_{t}\right)\right]^{-1}\right]-\left[\alpha\left(1-\tau_{t}^{M}\right)^{-1}\right]+ \\
& {\left[\theta\left(\delta_{t+1}^{M}\right)^{-1} \frac{\partial \delta^{M}\left(Q_{t}, \tau_{t}^{M}, N, Z\right)}{\partial \tau_{t}^{M}}\right]+} \\
& \left.\left[(1-\beta)(1-\alpha-\theta)\left(\delta_{t+1}^{N}\right)^{-1} \frac{\partial \delta^{N}\left(Q_{t}, \tau_{t}^{M}, N, Z\right)}{\partial \tau_{t}^{M}}\right]\right\}\left[\left(\theta\left(\delta_{t+1}^{M}\right)^{-1}\right)+\left(\alpha b_{t}^{M}\left(a Q_{t}\right)^{-1}\right)\right]- \\
& \left.\left[\theta\left(\delta_{t+1}^{M}\right)^{-2} \frac{\partial \delta^{M}\left(Q_{t}, \tau_{t}^{M}, N, Z\right)}{\partial \tau_{t}^{M}}\right]\right\}
\end{aligned}
$$

Therefore,

$$
\begin{aligned}
& \frac{\partial y_{t+1}^{M}}{\partial \tau_{t}^{M}}=0 \text { implies that in the following equation, } \\
& \left\{\left\{\left[(1-\alpha-\beta+\alpha \beta+\theta \beta) h^{\prime}\left(\tau_{t}^{M} a Q_{t}\right)\left[h\left(\tau_{t}^{M} a Q_{t}\right)\right]^{-1}\right]-\left[\alpha\left(1-\tau_{t}^{M}\right)^{-1}\right]+\right.\right. \\
& {\left[\theta\left(\delta_{t+1}^{M}\right)^{-1} \frac{\partial \delta^{M}\left(Q_{t}, \tau_{t}^{M}, N, Z\right)}{\partial \tau_{t}^{M}}\right]+}
\end{aligned}
$$




$$
\begin{aligned}
& \left.\left[(1-\beta)(1-\alpha-\theta)\left(\delta_{t+1}^{N}\right)^{-1} \frac{\partial \delta^{N}\left(Q_{t}, \tau_{,}^{M}, N, Z\right)}{\partial \tau_{t}^{M}}\right]\right\}\left[\left(\theta\left(\delta_{t+1}^{M}\right)^{-1}\right)+\left(\alpha b_{t}^{M}\left(a Q_{t}\right)^{-1}\right)\right]- \\
& \left.\left[\theta\left(\delta_{t+1}^{M}\right)^{-2} \frac{\partial \delta^{M}\left(Q_{t}, \tau_{t}^{M}, N, Z\right)}{\partial \tau_{t}^{M}}\right]\right\}=0
\end{aligned}
$$

Hence the tax rate preferred by the manufacturers satisfies the following equation,

$$
\begin{aligned}
& \left\{\left[(1-\alpha-\beta+\alpha \beta+\theta \beta) h^{\prime}\left(\tau_{t}^{M} a Q_{t}\right)\left[h\left(\tau_{t}^{M} a Q_{t}\right)\right]^{-1}\right]+\left[\theta\left(\delta_{t+1}^{M}\right)^{-1} \frac{\partial \delta^{M}\left(Q_{t}, \tau_{t}^{M}, N, Z\right)}{\partial \tau_{t}^{M}}\right]+\right. \\
& \left.\left[(1-\beta)(1-\alpha-\theta)\left(\delta_{t+1}^{N}\right)^{-1} \frac{\partial \delta^{N}\left(Q_{t}, \tau_{t}^{M}, N, Z\right)}{\partial \tau_{t}^{M}}\right]\right\}\left[\left(\theta\left(\delta_{t+1}^{M}\right)^{-1}\right)+\left(\alpha b_{t}^{M}\left(a Q_{t}\right)^{-1}\right)\right]= \\
& \left\{\left[\alpha\left(1-\tau_{t}^{M}\right)^{-1}\right]\left[\left(\theta\left(\delta_{t+1}^{M}\right)^{-1}\right)+\left(\alpha b_{t}^{M}\left(a Q_{t}\right)^{-1}\right)\right]\right\}+\left[\theta\left(\delta_{t+1}^{M}\right)^{-2} \frac{\partial \delta^{M}\left(Q_{t}, \tau_{,}^{M}, N, Z\right)}{\partial \tau_{t}^{M}}\right]
\end{aligned}
$$

The tax rate satisfying the above equality, $\tau_{t}^{M}$, is the tax rate which maximizes second period income of the manufacturers. Thus,

$$
\tau_{t}^{M}=\operatorname{argmaxy}_{t+1}^{M}
$$

\section{A.3. Preferred Tax Rate of the Landowners}

Following from (22) and (29) the income function of landowners in period $t+1$ can be written as,

$$
\begin{aligned}
& y_{t+1}^{A}= \\
& {[\theta(1-} \\
& \left.\left.\tau_{t}^{A}\right)^{\alpha}\left(a Q_{t}\right)^{\alpha}\left[h\left(\tau_{t}^{A} a Q_{t}\right)\right]^{(1-\alpha-\beta+\alpha \beta+\theta \beta)}\left(\delta_{t+1}^{M}\right)^{\theta-1} N^{\beta(1-\alpha-\theta)}\left(\delta_{t+1}^{N}\right)^{(1-\beta)(1-\alpha-\theta)}\right]+ \\
& {\left[\left(\frac{1}{\mu}\right) \gamma Z^{\gamma}\left(1-\delta_{t+1}^{N}-\delta_{t+1}^{M}\right)^{1-\gamma}\right]}
\end{aligned}
$$


By taking the derivative of the income function of landowners in period $t+1$ with respect to their preferred tax rate, $\tau_{t}{ }^{A}$, we can obtain both the benefit and the cost of supporting human capital accumulation for the landowners.

$$
\begin{aligned}
& \frac{\partial y_{t+1}^{A}}{\partial \tau_{t}{ }^{A}}=0 \text { implies that } \\
& \theta(1- \\
& \left.\tau_{t}^{A}\right)^{\alpha}\left(a Q_{t}\right)^{\alpha}\left[h\left(\tau_{t}^{A} a Q_{t}\right)\right]^{(1-\alpha-\beta+\alpha \beta+\theta \beta)}\left(\delta_{t+1}^{M}\right)^{\theta-1} N^{\beta(1-\alpha-\theta)}\left(\delta_{t+1}^{N}\right)^{(1-\beta)(1-\alpha-\theta)}\{[(1- \\
& \left.\alpha-\beta+\alpha \beta+\theta \beta) h^{\prime}\left(\tau_{t}^{A} a Q_{t}\right)\left[h\left(\tau_{t}^{A} a Q_{t}\right)\right]^{-1}\right]-\left[\alpha\left(1-\tau_{t}^{A}\right)^{-1}\right]+ \\
& \left.\left[(\theta-1)\left(\delta_{t+1}^{M}\right)^{-1} \frac{\partial \delta^{M}\left(Q_{t}, \tau_{t}^{A}, N, Z\right)}{\partial \tau_{t}^{A}}\right]+\left[(1-\beta)(1-\alpha-\theta)\left(\delta_{t+1}^{N}\right)^{-1} \frac{\partial \delta^{N}\left(Q_{t}, \tau_{t}^{A}, N, Z\right)}{\partial \tau_{t}^{A}}\right]\right\}+ \\
& {\left[\left(\frac{1}{\mu}\right)(1-\gamma) \gamma Z^{\gamma}\left(1-\delta_{t+1}^{N}-\delta_{t+1}^{M}\right)^{-\gamma} \frac{\partial \delta^{N}\left(Q_{t}, \tau_{t}{ }^{A}, N, Z\right)}{\partial \tau_{t}{ }^{A}} \frac{\partial \delta^{M}\left(Q_{t}, \tau_{t}{ }^{A}, N, Z\right)}{\partial \tau_{t}{ }^{A}}\right]=0}
\end{aligned}
$$

The tax rate satisfying this equality, $\tau_{t}^{A}$, is the tax rate which maximizes the second period income of the landowners. Hence,

$$
\tau_{t}^{A}=\operatorname{argmax} y_{t+1}^{A}
$$

\section{A.4. Preferred Tax Rate of the Natural Resource Owners}

As follows from (24) and (31),

$$
y_{t+1}^{N}=w\left(Q_{t} \tau_{t}{ }^{N}, N, Z\right)+\left(1-\tau_{t}^{N}\right) b_{t}^{N} R\left(Q_{t}, \tau_{t}{ }^{N}, N, Z\right)+(N / \sigma) v\left(Q_{t}, \tau_{t}{ }^{N}, N, Z\right)
$$

Following from (15), (16), (22) and Section A.2 in the Appendix, we can write $y_{t+1}^{N}$ as,

$$
\begin{aligned}
& y_{t+1}^{N}= \\
& {\left[(1-\beta) N^{\beta}\left(\delta_{t+1}^{N}\right)^{-\beta}\left[h\left(\tau_{t}^{N} a Q_{t}\right)\right]^{(1-\beta)}\right]+}
\end{aligned}
$$


$\left[\alpha b_{t}^{N}(1-\right.$

$\left.\left.\tau_{t}^{N}\right)^{\alpha}\left(a Q_{t}\right)^{\alpha-1}\left[h\left(\tau_{t}^{N} a Q_{t}\right)\right]^{(\theta)}\left(\delta_{t+1}^{M}\right)^{\theta} N^{\beta(1-\alpha-\theta)}\left(\delta_{t+1}^{N}\right)^{(1-\beta)(1-\alpha-\theta)}\left[h\left(\tau_{t}^{N} a Q_{t}\right)\right]^{(1-\alpha-\theta)(1-\beta)}\right]+$

$\left[\left(\frac{1}{\sigma}\right) \beta N^{\beta}\left(\delta_{t+1}^{N}\right)^{1-\beta}\left[h\left(\tau_{t}^{N} a Q_{t}\right)\right]^{(1-\beta)}\right]$

This expression can be simplified as in the following equation,

$y_{t+1}^{N}=\left\{N^{\beta}\left(\delta_{t+1}^{N}\right)^{-\beta}\left[h\left(\tau_{t}^{N} a Q_{t}\right)\right]^{(1-\beta)}\left[(1-\beta)+\left(\frac{1}{\sigma}\right) \beta \delta_{t+1}^{N}\right]\right\}+\left\{\alpha b_{t}^{N}(1-\right.$

$\left.\left.\tau_{t}^{N}\right)^{\alpha}\left(a Q_{t}\right)^{\alpha-1}\left[h\left(\tau_{t}^{N} a Q_{t}\right)\right]^{(1-\alpha-\beta+\alpha \beta+\theta \beta)}\left(\delta_{t+1}^{M}\right)^{\theta} N^{\beta(1-\alpha-\theta)}\left(\delta_{t+1}^{N}\right)^{(1-\beta)(1-\alpha-\theta)}\right\}$

Taking the derivative of the second period income function of the natural resource owners with respect to their preferred tax rate, $\tau_{t}^{N}$, gives us the following equation,

$\frac{\partial y_{t+1}^{N}}{\partial \tau_{t}^{N}}=0$ implies that

$$
\begin{aligned}
& \left\{N ^ { \beta } ( \delta _ { t + 1 } ^ { N } ) ^ { - \beta } [ h ( \tau _ { t } ^ { N } a Q _ { t } ) ] ^ { ( 1 - \beta ) } \left\{\left[\left(-\beta \frac{\partial \delta^{N}\left(Q_{t}, \tau_{t}^{N}, N, Z\right)}{\partial \tau_{t}^{N}}\left(\delta_{t+1}^{N}\right)^{-1}\right)+\right.\right.\right. \\
& \left.\left.\left((1-\beta) h^{\prime}\left(\tau_{t}^{N} a Q_{t}\right)\left[h\left(\tau_{t}^{N} a Q_{t}\right)\right]^{-1}\right)\right]\left[(1-\beta)+\left(\frac{1}{\sigma}\right) \beta \delta_{t+1}^{N}\right]+\left[\left(\frac{1}{\sigma}\right) \beta \frac{\partial \delta^{N}\left(Q_{t}, \tau_{t}^{N}, N, Z\right)}{\partial \tau_{t}^{N}}\right]\right\}+ \\
& \left\{\alpha b_{t}^{N}(1-\right. \\
& \left.\tau_{t}^{N}\right)^{\alpha}\left[h\left(\tau_{t}^{N} a Q_{t}\right)\right]^{(1-\alpha-\beta+\alpha \beta+\theta \beta)}\left(a Q_{t}\right)^{\alpha-1} N^{\beta(1-\alpha-\theta)}\left(\delta_{t+1}^{N}\right)^{(1-\beta)(1-\alpha-\theta)}\left(\delta_{t+1}^{M}\right)^{\theta}\{[(1- \\
& \left.\alpha-\beta+\alpha \beta+\theta \beta) h^{\prime}\left(\tau_{t}^{N} a Q_{t}\right)\left[h\left(\tau_{t}^{N} a Q_{t}\right)\right]^{-1}\right]-\left[\alpha\left(1-\tau_{t}^{N}\right)^{-1}\right]+ \\
& \left.\left.\left[\theta\left(\delta_{t+1}^{M}\right)^{-1} \frac{\partial \delta^{M}\left(Q_{t}, \tau_{t}^{N}, N, Z\right)}{\partial \tau_{t}^{N}}\right]+\left[(1-\beta)(1-\alpha-\theta)\left(\delta_{t+1}^{N}\right)^{-1} \frac{\partial \delta^{N}\left(Q_{t}, \tau_{t}^{N}, N, Z\right)}{\partial \tau_{t}^{N}}\right]\right\}\right\}=0
\end{aligned}
$$

Hence, in order to satisfy the above equality and maximize the income of the natural resource owners in period $t+1$, it requires a tax rate, $\tau_{t}^{N}$, higher than the tax rate preferred by the manufacturers, $\tau_{t}^{M}$. 
Then, $\tau_{t}^{N}=\operatorname{argmaxy} y_{t+1}^{N}$

$\tau_{t}^{N}=$

$\operatorname{argmax}\left[w\left(Q_{t}, \tau_{t}^{N}, N, Z\right)+\left(1-\tau_{t}^{N}\right) b_{t}^{N} R\left(Q_{t}, \tau_{t}{ }^{N}, N, Z\right)+(N / \sigma) v\left(Q_{t}, \tau_{t}{ }^{N}, N, Z\right)\right]$

Therefore, the tax rate, $\tau_{t}^{N}$, maximizing the second period income of natural resource owners also satisfies the following condition,

$\tau_{t}^{N}>\tau_{t}^{M}=\tau_{t}^{*}>\tau_{t}^{A}$

\section{A.5. Preferred Tax Policy of the Manufacturers-Natural Resource Owners Coalition}

The political coalition of manufacturers and natural resource owners will prefer a tax rate, $\tau_{t}^{M N}$, which maximizes their joint second period income. The simulation results imply that following from (24) and (33), the joint second period income function can be written as

$$
\begin{aligned}
y_{t+1}^{M N}= & {\left[w\left(Q_{t}, \tau_{t}^{M N}, N, Z\right)+\left(1-\tau_{t}^{M N}\right) b_{t}^{M} R\left(Q_{t}, \tau_{t}^{M N}, N, Z\right)\right]+\left[w\left(Q_{t}, \tau_{t}^{M N}, N, Z\right)+\right.} \\
& \left.\left(1-\tau_{t}^{M N}\right) b_{t}^{N} R\left(Q_{t} \tau_{t}^{M N}, N, Z\right)+\left(\frac{N}{\sigma}\right) v\left(Q_{t} \tau_{t}^{M N}, N, Z\right)\right]
\end{aligned}
$$

Taking the derivative of the second period income function of the manufacturers - natural resource owners coalition with respect to their preferred tax rate, $\tau_{t}^{M N}$, gives us the following equation,

$\frac{\partial y_{t+1}^{M N}}{\partial \tau_{t}^{M N}}=0$ implies that 


$$
\begin{aligned}
& \left\{N ^ { \beta } ( \delta _ { t + 1 } ^ { N } ) ^ { - \beta } [ h ( \tau _ { t } ^ { M N } a Q _ { t } ) ] ^ { ( 1 - \beta ) } \left\{\left[\left(-\beta \frac{\partial \delta^{N}\left(Q_{t}, \tau_{t}^{M N}, N, Z\right)}{\partial \tau_{t}^{M N}}\left(\delta_{t+1}^{N}\right)^{-1}\right)+\right.\right.\right. \\
& \left.\left((1-\beta) h^{\prime}\left(\tau_{t}^{M N} a Q_{t}\right)\left[h\left(\tau_{t}^{M N} a Q_{t}\right)\right]^{-1}\right)\right]\left[(1-\beta)+\left(\frac{1}{\sigma}\right) \beta \delta_{t+1}^{N}\right]+ \\
& \left.\left[\left(\frac{1}{\sigma}\right) \beta \frac{\partial \delta^{N}\left(Q_{t}, \tau_{t}^{M N}, N, Z\right)}{\partial \tau_{t}^{M N}}\right]\right\}+ \\
& (1- \\
& \left.\tau_{t}^{M N}\right)^{\alpha}\left(a Q_{t}\right)^{\alpha}\left[h\left(\tau_{t}^{M N} a Q_{t}\right)\right]^{(1-\alpha-\beta+\alpha \beta+\theta \beta)}\left(\delta_{t+1}^{M}\right)^{\theta} N^{\beta(1-\alpha-\theta)}\left(\delta_{t+1}^{N}\right)^{(1-\beta)(1-\alpha-\theta)}\{\{[(1- \\
& \left.\alpha-\beta+\alpha \beta+\theta \beta) h^{\prime}\left(\tau_{t}^{M N} a Q_{t}\right)\left[h\left(\tau_{t}^{M N} a Q_{t}\right)\right]^{-1}\right]-\left[\alpha\left(1-\tau_{t}^{M N}\right)^{-1}\right]+ \\
& {\left[\theta\left(\delta_{t+1}^{M}\right)^{-1} \frac{\partial \delta^{M}\left(Q_{t}, \tau_{t}^{M N}, N, Z\right)}{\partial \tau_{t}^{M N}}\right]+} \\
& \left.\left[(1-\beta)(1-\alpha-\theta)\left(\delta_{t+1}^{N}\right)^{-1} \frac{\partial \delta^{N}\left(Q_{t}, \tau_{t}^{M N}, N, Z\right)}{\partial \tau_{t}^{M N}}\right]\right\}\left[\left(\theta\left(\delta_{t+1}^{M}\right)^{-1}\right)+\left(\alpha b_{t}^{M}\left(a Q_{t}\right)^{-1}\right)+\right. \\
& \left.\left.\left(\alpha b_{t}^{N}\left(a Q_{t}\right)^{-1}\right)\right]-\left[\theta\left(\delta_{t+1}^{M}\right)^{-2} \frac{\partial \delta^{M}\left(Q_{t}, \tau_{t}^{M N}, N, Z\right)}{\partial \tau_{t}^{M N}}\right]\right\}=0
\end{aligned}
$$

The tax rate satisfying the above equality, $\tau_{t}^{M N}$, is the tax rate which maximizes second period income of the manufacturers - natural resource owners coalition members.

Then, $\tau_{t}^{M N}=\operatorname{argmax} y_{t+1}^{M N}$

\section{A.6. Preferred Tax Policy of the Manufacturers-Landowners Coalition}

The second period income function of the coalition, (35), can also be written as the following

$$
\begin{aligned}
y_{t+1}^{M A}= & {\left[w\left(Q_{t}, \tau_{t}^{M A}, N, Z\right)+\left(1-\tau_{t}^{M A}\right) b_{t}^{M} R\left(Q_{t}, \tau_{t}^{M A}, N, Z\right)\right]+\left[w\left(Q_{t}, \tau_{t}{ }^{M A}, N, Z\right)+\right.} \\
& \left.s^{A} x\left(Q_{t}, \tau_{t}{ }^{M A}, N, Z\right)\right]
\end{aligned}
$$


The political coalition of manufacturers and landowners will implement a tax policy for human capital accumulation using the tax rate, $\tau_{t}^{M A}$, such as maximizing their second period income as in the following equation,

$$
\begin{aligned}
& \frac{\partial y_{t+1}^{M A}}{\partial \tau_{t}^{M A}}=0 \text { implies that } \\
& (1- \\
& \left.\tau_{t}^{M A}\right)^{\alpha}\left[h\left(\tau_{t}^{M A} a Q_{t}\right)\right]^{(1-\alpha-\beta+\alpha \beta+\theta \beta)}\left(a Q_{t}\right)^{\alpha} N^{\beta(1-\alpha-\theta)}\left(\delta_{t+1}^{N}\right)^{(1-\beta)(1-\alpha-\theta)}\left(\delta_{t+1}^{M}\right)^{\theta}\{\{[(1- \\
& \left.\alpha-\beta+\alpha \beta+\theta \beta) h^{\prime}\left(\tau_{t}^{M A} a Q_{t}\right)\left[h\left(\tau_{t}^{M A} a Q_{t}\right)\right]^{-1}\right]-\left[\alpha\left(1-\tau_{t}^{M A}\right)^{-1}\right]+ \\
& {\left[\theta\left(\delta_{t+1}^{M}\right)^{-1} \frac{\partial \delta^{M}\left(Q_{t}, \tau_{t}^{M A}, N, Z\right)}{\partial \tau_{t}^{M A}}\right]+} \\
& {\left[(1-\beta)(1-\alpha-\theta)\left(\delta_{t+1}^{N}\right)^{-1} \frac{\partial \delta^{N}\left(Q_{t}, \tau_{t}^{M A}, N, Z\right)}{\partial \tau_{t}^{M A}}\right]\left[\left(\theta\left(\delta_{t+1}^{M}\right)^{-1}\right)+\left(\alpha b_{t}^{M}\left(a Q_{t}\right)^{-1}\right)\right]-} \\
& \left.\left[\theta\left(\delta_{t+1}^{M}\right)^{-2} \frac{\partial \delta^{M}\left(Q_{t}, \tau_{t}^{M}, N, Z\right)}{\partial \tau_{t}^{M}}\right]\right\}+ \\
& \left\{[ \theta ( \delta _ { t + 1 } ^ { M } ) ^ { - 1 } ] \left\{\left[(1-\alpha-\beta+\alpha \beta+\theta \beta) h^{\prime}\left(\tau_{t}^{M A} a Q_{t}\right)\left[h\left(\tau_{t}^{M A} a Q_{t}\right)\right]^{-1}\right]-[\alpha(1-\right.\right. \\
& \left.\left.\tau_{t}^{M A}\right)^{-1}\right]+\left[(\theta-1)\left(\delta_{t+1}^{M}\right)^{-1} \frac{\partial \delta^{M}\left(Q_{t}, \tau_{t}^{M A}, N, Z\right)}{\partial \tau_{t}^{M A}}\right]+ \\
& \left.\left[(1-\beta)(1-\alpha-\theta)\left(\delta_{t+1}^{N}\right)^{-1} \frac{\partial \delta^{N}\left(Q_{t}, \tau_{t}^{M A}, N, Z\right)}{\partial \tau_{t}^{M A}}\right]\right\}+\left[( \frac { 1 } { \mu } ) ( 1 - \gamma ) \gamma Z ^ { \gamma } \left(1-\delta_{t+1}^{N}-\right.\right. \\
& \left.\left.\delta_{t+1}^{M}\right)^{-\gamma} \frac{\partial \delta^{N}\left(Q_{t}, \tau_{t}^{M A}, N, Z\right)}{\partial \tau_{t}^{M A}} \frac{\partial \delta^{M}\left(Q_{t}, \tau_{t}^{M A}, N, Z\right)}{\partial \tau_{t}^{M A}}\right]=0
\end{aligned}
$$

Therefore, $\tau_{t}^{M A}$ is the tax rate maximizing the second period income of the manufacturers - landowners coalition members, so

$$
\tau_{t}^{M A}=\operatorname{argmax} y_{t+1}^{M A}
$$


And, $\tau_{t}^{M A}=\tau_{t}^{M}=\tau_{t}^{*}$, and following (26), (27), (28)

$$
\begin{aligned}
& \tau_{t}^{M A} \equiv \operatorname{argmax} Q_{t+1}, \text { and } \\
& \tau_{t}^{N}>\tau_{t}^{M N}>\tau_{t}^{M A}=\tau_{t}^{M}=\tau_{t}^{*}>\tau_{t}^{A}
\end{aligned}
$$


VITA

ECE HANDAN GULERYUZ

June 27, 1982

2003-2007

2007-2008

2007-2009

2009-2011

2010-2012
Born, Cyprus

B.S., Economics

Middle East Technical University

Ankara, Turkey

M.A., Economics

Florida International University

Miami, Florida

Teaching Assistant

Florida International University

Miami, Florida

Instructor

Florida International University

Miami, Florida

Doctoral Candidate

Florida International University

Miami, Florida

\section{PRESENTATIONS}

Guleryuz, E. H., (February, 2011). Political Conflict, Natural Resource Abundance and Human Capital. Paper presented at the meeting of the Eastern Economic Association, New York City, New York.

Guleryuz, E. H., (March, 2011). Political Conflict, Natural Resource Abundance and Human Capital. Paper presented at the meeting of the Midwest Economics Association, St. Louis, Missouri.

Guleryuz, E. H., (January, 2012). Political Conflict, Natural Resource Abundance and Human Capital. Paper presented at the 7th Royal Economic Society PhD Meeting, London, United Kingdom. 
Guleryuz, E. H., (March, 2012). Social Class Structure and Political Economy of Public Education Spending. Paper presented at the meeting of the Eastern Economic Association, Boston, Massachusetts.

Guleryuz, E. H., (March, 2012). Social Class Structure and Political Economy of Public Education Spending. Paper presented at the meeting of the Midwest Economics Association, Evanston, Illinois. 